Article

\title{
Winter Wheat Grain Quality, Zinc and Iron Concentration Affected by a Combined Foliar Spray of Zinc and Iron Fertilizers
}

\author{
Etienne Niyigaba, Angelique Twizerimana, Innocent Mugenzi, Wansim Aboubakar Ngnadong, \\ Yu Ping Ye, Bang Mo Wu and Jiang Bo Hai *
}

Department of crop cultivation and farming system, College of Agronomy, Northwest A\&F University, Yangling, Shaanxi 712100, China; niyigabat@gmail.com (E.N.); atwizerimana@gmail.com (A.T.); mugenziinn@gmail.com (I.M.); aboubakar777@yahoo.fr (W.A.N.); 2012010065@nwafu.edu.cn (Y.P.Y.); wu_bangmo@126.com (B.M.W.)

* Correspondence: haijiangbo@126.com; Tel.: +86-13389221092

Received: 19 April 2019; Accepted: 15 May 2019; Published: 20 May 2019

\begin{abstract}
Wheat (Triticum aestivum L.) is one of the main foods globally. Nutrition problems associated with Zinc and Iron deficiency affect more than two billion individuals. Biofortification is a strategy believed to be sustainable, economical and easily implemented. This study evaluated the effect of combined $\mathrm{Zn}$ and Fe applied as foliar fertilizer to winter wheat on grain yield, quality, $\mathrm{Zn}$ and Fe concentration in the grains. Results showed that treatments containing high Fe increased the yield. Grain crude fat content remained unaffected. Crude fiber was enhanced up to three-fold by $60 \% \mathrm{Zn}+40 \% \mathrm{Fe}_{5.5}\left(5.5 \mathrm{~kg} \mathrm{ha}{ }^{-1}\right.$ of $\left.60 \% \mathrm{Zn}+40 \% \mathrm{Fe}\right)$. Moreover, $80 \% \mathrm{Zn}+20 \% \mathrm{Fe}_{5.5}\left(5.5 \mathrm{~kg} \mathrm{ha}{ }^{-1}\right.$ of $80 \% \mathrm{Zn}+20 \% \mathrm{Fe}$ ) was the best combination for increasing crude protein. Zinc applied alone enhanced Zn concentration in grain. In addition, Fe was slightly improved by an application of Zn and $\mathrm{Fe}$ in the first year, but a greater increase was observed in the second year, where $100 \% \mathrm{Fe}_{13}$ (13 kg ha ${ }^{-1}$ of $100 \% \mathrm{Fe}$ ) was the best in improving Fe in grain. Foliar application of $\mathrm{Zn}$ and Fe is a practical approach to increase $\mathrm{Zn}$ and Fe concentration, and to improve the quality of wheat grains.
\end{abstract}

Keywords: combined zinc and iron fertilizers; foliar spray; agronomic biofortification; wheat

\section{Introduction}

Wheat (Triticum aestioum L.) is among the top cereal crops cultivated in the world, together with maize and rice. They contribute to edible dry matter, and daily calorie intake, up to $28 \%$ and $60 \%$, respectively, in developing countries (GNI < \$12,055) [1-3]. However, in developing countries, nutrition deficiency is a serious problem associated with poor diet. Food and nutrient intake constitute the basis of life; people are dying en masse due to a lack of sufficient nutrients [4]. This problem resulted in the deaths of about 30 million people in 2003 in developing countries with poor resources [5,6]. As reported by Graham [4], every second, one person dies of disease related to diet. Moreover, Fe deficiency affects more than two billion individuals, or one in three people globally [7,8], while about $30 \%$ of people in developing countries and 10\% of Americans and Canadians are Zn deficient [9]. The World Health Organization estimates that approximately $25 \%$ of the world's population suffers from anemia [10], and that Fe deficiency anemia led to the loss of over 46,000 disability-adjusted life years (DALYs) in 2010 alone [11]. An estimated 17.3\% of people worldwide are at risk of inadequate Zn intake, and $\mathrm{Zn}$ deficiency leads to estimated annual deaths of 433,000 children under the age of 5 [12].

Recently, it was reported that in the UK, the Zn intake of about a quarter of adolescents is below the lower reference nutrient intake (LRNI) and the Fe intake of over half of all adolescent girls and over a quarter of adult women is below the LRNI $[13,14]$. Nutrient-deficient food and diet related problems 
are the main cause of death on Earth, and this can be prevented by supplying nutrients in a sustainable manner, and finding solutions to malnutrition [4].

The human body needs 51 essential nutrients, and a short supply or lack of even one of these can cause metabolic problems resulting in poor health, sickness, and economic and social costs to the community $[4,7,15,16]$. These nutrients are supplied only from agricultural products (excluding water and oxygen). The green revolution has boosted crop yield, and has prevented people from starving in many countries through the high production of cereal crops (wheat, maize and rice) [4]. However, the cereal monoculture system has enhanced the micronutrient deficiency problem by eliminating diverse cropping systems that provided micronutrient-rich food for poor communities [17]. In addition, breeding of high-yielding crops has caused a significant "dilution effect" of essential nutrients, such as $\mathrm{Zn}$ and Fe [18-20]; Cakmak reported that modern breeds have high yield, but their respective wild types present from two to three-fold more Zn [21,22]. However, wheat is inherently low in Zn, and its consumption in rural areas is likely to increase to more than $70 \%$, which amplifies the magnitude of nutrient deficiency in communities with poor resources [23].

Cereals contribute up to $60 \%$ and $52 \%$ of the daily micronutrient requirement for $\mathrm{Fe}$ and $\mathrm{Zn}$, respectively [24]. Therefore, it is important to focus on the important food crops that maintain human life in most countries. Several initiatives are now in place to deeply study and contribute to the nutritional quality of food. For instance HarvestPlus, the Biofortification Challenge Program established by the Consultative Group on International Agricultural Research (CGIAR), is focusing on enhancing major staple crops with $\mathrm{Fe}, \mathrm{Zn}$ and $\beta$-carotene $[4,18]$.

Biofortification is a process of developing high micronutrient food crops by traditional breeding or modern biotechnology. Biofortification of staple crops has had major developments recently: Orange-flesh sweet potato, with high $\beta$-carotene (over $200 \mu \mathrm{g} / \mathrm{g}$ ), beans with $50-70 \%$ more Fe, golden rice with $37 \mu \mathrm{g} / \mathrm{g}$ carotenoid, of which $31 \mu \mathrm{g} / \mathrm{g}$ is $\beta$-carotene, have been bred to date. Moreover, research is taking place to increase genetically the Fe in rice grain endosperm from the aleurone layer, which is removed when producing polished rice [25]. It was reported that the $\mathrm{Zn}$ concentration of most cultivated areas range between 20 and $35 \mathrm{mg} \mathrm{kg}^{-1}$, and it could be far below this when wheat is grown on zinc-poor soils $[4,18,26,27]$. These concentrations cannot meet daily $\mathrm{Zn}$ requirements to reach the target range for human health, which is $40-50 \mathrm{mg} \mathrm{kg}^{-1}[4,27,28]$.

In wheat grains, the bioavailability of $\mathrm{Zn}$ is about $25 \%$, while that of $\mathrm{Fe}$ is assumed to be $5 \%$. The bioavailability of $\mathrm{Fe}$ and $\mathrm{Zn}$ is associated with the presence of antinutrients, such as phytate and a lack of promoter substances in grains [7,29]. Any breeding or biofortification program should consider increasing not only the quantity of micronutrients, but also their bioavailability [22].

Some nutrients facilitate the uptake and remobilization of $\mathrm{Fe}$ and $\mathrm{Zn}$ in plants. For instance, the combination of nitrogen fertilizer with $\mathrm{Zn}$ and Fe applied in soil or on leaves increases both the yield and the uptake of these elements [27,30]. In wheat, the translocation of $\mathrm{Zn}$ and Fe from flag leaves to grains is also facilitated by metal-chelating compounds, such as 2-deoxymugineic acid (DMA) [31]. At a high $\mathrm{N}$ rate, a great part of total shoot $\mathrm{Zn}$ and $\mathrm{Fe}$, nearly $80 \%$ and $60 \%$, respectively, was found in grains, highlighting the role of $\mathrm{N}$ in supporting the movement of $\mathrm{Zn}$ and Fe in wheat [32]. Similarly, Erenoglu [33] illustrated that biofortification of food crops needs to take into consideration the critical role of nitrogen in the uptake and accumulation of Zn. Furthermore, HarvestPlus reported a positive effect of Nitrogen upon the concentration of $\mathrm{Zn}$ and $\mathrm{Fe}$ in wheat. This relationship allows the increase of multiple micronutrients simultaneously [22]. The role of nitrogen in facilitating the uptake, transport, translocation, and deposits of micronutrients, especially $\mathrm{Zn}$ and Fe in cereal grains, has been extensively studied, and reports are available [8,32-36]. Moreover, S (sulfur) is another element that was repeatedly reported in assisting Fe and Zn metabolism in plants. The plant's ability to absorb and accumulate Fe was proven to be dependent upon $S$ presence in the growing medium in cereal crops $[37,38]$.

The release of phytosiderophores that help Fe uptake by the roots has a positive correlation with $S$ accumulation, and this process can increase the Fe use efficiency of roots, hence alleviating the effect of 
Fe deficiency $[38,39]$. Astolfi et al. reported an important finding in the biofortification of wheat grains with $\mathrm{Zn}$ that, irrespective of the $\mathrm{S}$ application level, the $\mathrm{Zn}$ concentration in durum seed remained higher in Fe-deficient plants, compared to control plants, and the study revealed that $S$ fertilization can alleviate the Fe shortage stress without harmful effects on grain quality [40]. Several available resources demonstrate the $\mathrm{S}$ and Fe interaction in plants [37,38,40-43].

There are many possible strategies to improve micronutrient intake in the human diet, including dietary diversification, mineral supplementation, post-harvest food fortification and biofortification [44]. Plant breeding (e.g., genetic biofortification) and application of $\mathrm{Zn}$ and Fe fertilizers (e.g., agronomic biofortification), are two important agricultural tools to improve the grain concentration of $\mathrm{Zn}$ and $\mathrm{Fe}$ [22]. Even though genetic engineering opens more doors to increase dramatically the bioavailability of $\mathrm{Zn}$ and Fe in grains, its acceptability by consumers and regulatory bodies is very limited, and genetically modified crop cultivation and marketing are not likely to be relaxed in the near future [13]. Agronomic biofortification is achieved by applying micronutrients to the soil and/or directly to the leaves of the crop [45]. In contrast to genetic engineering, agronomic biofortification is potentially more sustainable, more economical, and more easily implemented than other strategies [23,46,47].

Foliar application of nutrients is an important crop management strategy to maximize crop yields and concentrations of micronutrients in edible parts. Several studies have demonstrated that foliar application of micronutrients, including $\mathrm{Zn}$ and Fe, showed good behavior in increasing their concentration in wheat grain [27,48-52]. However, little is known about the effect of combined $\mathrm{Zn}$ and Fe on the quality of this wheat grain. Therefore, this study was conducted to closely assess the combined effect of $\mathrm{Zn}$ and Fe applied as foliar fertilizer at different growth stages of winter wheat on crop performance, grain yield and grain quality.

\section{Materials and Methods}

\subsection{Field Location}

This experiment was conducted during the winter wheat cropping seasons of 2016-2017 and 2017-2018 at the Doukou Wheat and Maize Demonstration Research Station (108 $52^{\prime}$ E, $\left.34^{\circ} 36^{\prime} \mathrm{N}\right)$ of Northwest A\&F University, Shaanxi Province, China. The site's climate is classified as semi-humid. The average temperature during the trials period was $9.5^{\circ} \mathrm{C}$ and $10.4{ }^{\circ} \mathrm{C}$, during $2016-2017$ and 2017-2018 season, respectively (Figure 1). The average precipitation was $16.4 \mathrm{~mm}$ and $11.6 \mathrm{~mm}$, during 2016-2017 and 2017-2018 season, respectively (Figure 1). In addition, the station's average annual solar radiation is $247.35 \mathrm{~kJ} \mathrm{~cm}^{-2}$, the average annual sunshine duration is $2271.6 \mathrm{~h}$, and the sunshine percentage is $51 \%$. The average annual frost-free period is about 220 days, while the average annual precipitation is $595 \mathrm{~mm}$, and the average annual land surface evaporation is $417.6 \mathrm{~mm}$. The soil used is classified as Earth-Cumuli Orthic anthrosol, with total $\mathrm{N}$ of $151.00 \mathrm{mg} \mathrm{kg}^{-1}$, available $\mathrm{K}$ of $26.97 \mathrm{mg}$ $\mathrm{kg}^{-1}$, available $\mathrm{P}$ of $198.54 \mathrm{mg} \mathrm{kg}^{-1}$, $\mathrm{pH}$ of 8.04 (alkali), extractable $\mathrm{Zn}$ of $1.35 \mathrm{mg} \mathrm{kg}^{-1}$ and extractable Fe of $7.87 \mathrm{mg} \mathrm{kg}^{-1}$. The soil used is classified as having high $\mathrm{Zn}$ and Fe content [53].
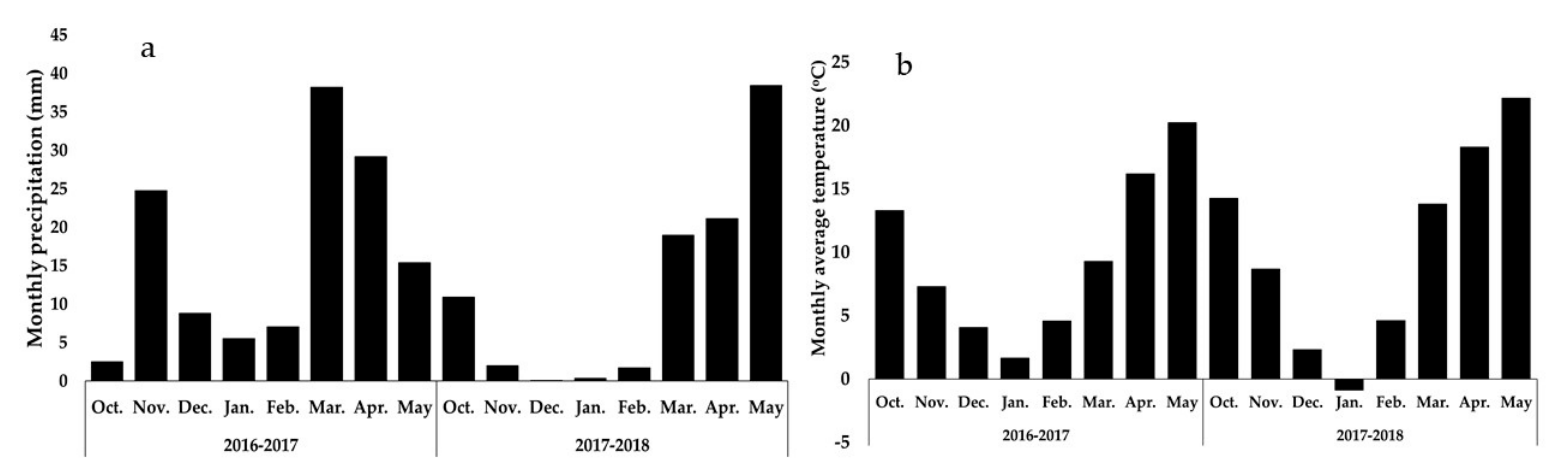

Figure 1. Meteorological data during both cropping seasons: (a) Monthly precipitation, (b) monthly average temperature. 


\subsection{Experimental Design and Treatments}

The experimental design consisted of split-plots in a randomized complete block design, with three replications. The experimental field consisted of treatments of $2.3 \mathrm{~m} \times 5 \mathrm{~m}$ plot size, with $21 \mathrm{~cm}$ row spacing, by Nongda 399 wheat cultivar, sown using a manual seed drill machine at a seeding rate of $225 \mathrm{~kg} \mathrm{ha}^{-1}$. During the second cropping season (2017-2018), wheat was grown on the same plots as the previous season, which were used after harvesting summer maize in the same field during both seasons. Basal fertilizers were applied according to local regulations with wheat special slow-release fertilizer $\left(\mathrm{N}-\mathrm{P}_{2} \mathrm{O}_{5}-\mathrm{K}_{2} \mathrm{O}: 24-15-5\right.$, total nutrient $\left.\geq 44 \%\right)$ applied at $750 \mathrm{~kg} \mathrm{ha}^{-1}$ before sowing. Plots were irrigated thrice in both growing seasons of 2016-2017 and 2017-2018; once at tillering stage and twice at elongation stage. Weeding was continuously done by hand uniformly to all plots, while a handheld pressure sprayer was used to apply pesticides.

Solutions of $\mathrm{Zn}$ and/or Fe fertilizers were sprayed with different $\mathrm{Zn} / \mathrm{Fe}$ ratios and doses. The spraying was done at different growth stages including booting stage (Feekes 10), anthesis (Feekes 10.51) and early filling stage (Feekes 10.54), using a handheld pressure sprayer. Spraying was done under windless conditions after sunset to avoid evaporation of the applied solution.

The main plots received different fertilizer ratios of combined or non-combined solutions of $\mathrm{Zn}$ used as $\mathrm{ZnSO}_{4} .7 \mathrm{H}_{2} \mathrm{O}$, and Fe used as $\mathrm{FeSO}_{4} .7 \mathrm{H}_{2} \mathrm{O}$ as follows: (1) $100 \% \mathrm{Zn}$, (2) $80 \% \mathrm{Zn}+20 \% \mathrm{Fe}$, (3) $60 \% \mathrm{Zn}+40 \% \mathrm{Fe}$, (4) $40 \% \mathrm{Zn}+60 \% \mathrm{Fe}$, (5) $20 \% \mathrm{Zn}+80 \% \mathrm{Fe}$, (6) $100 \%$ Fe. Every main plot had sub-plot treatments of fertilizer in the quantity of $0.5 \%(\mathrm{w} / \mathrm{v})$ as follows: $13,9.5,5.5$ and $0 \mathrm{~kg} \mathrm{ha}^{-1}$. The control plots $\left(0 \mathrm{~kg} \mathrm{ha}^{-1}\right.$ of $\mathrm{ZnSO}_{4} .7 \mathrm{H}_{2} \mathrm{O}$ and/or $\left.\mathrm{FeSO}_{4} .7 \mathrm{H}_{2} \mathrm{O}\right)$ were treated with a corresponding quantity of deionized water. The exact quantity of $\mathrm{Zn}$ and Fe applied in each treatment is presented in Table 1. The cultivar used in this study is a newly developed cultivar with strong resistance to cold, drought and diseases. Therefore, these quantities were selected and applied to test its resistance to different quantities of sprayed fertilizers.

Table 1. Meanings of symbol used for treatments.

\begin{tabular}{|c|c|}
\hline Symbol & Meaning of Symbol and Exact Quantity of Zn and Fe Applied \\
\hline $100 \% \mathrm{Zn}_{13}$ & $3.0 \mathrm{~kg} \mathrm{ha}^{-1}$ of $\mathrm{Zn}$ \\
\hline $100 \% \mathrm{Zn}_{9.5}$ & $2.2 \mathrm{~kg} \mathrm{ha}^{-1}$ of $\mathrm{Zn}$ \\
\hline $100 \% \mathrm{Zn}_{5.5}$ & $1.3 \mathrm{~kg} \mathrm{ha}^{-1}$ of $\mathrm{Zn}$ \\
\hline $80 \% \mathrm{Zn}+20 \% \mathrm{Fe}_{13}$ & $2.40 \mathrm{~kg} \mathrm{ha}^{-1}$ of $\mathrm{Zn}+0.52 \mathrm{~kg} \mathrm{ha}^{-1}$ of $\mathrm{Fe}$ \\
\hline $80 \% \mathrm{Zn}+20 \% \mathrm{Fe}_{9.5}$ & $1.76 \mathrm{~kg} \mathrm{ha}^{-1}$ of $\mathrm{Zn}+0.38 \mathrm{~kg} \mathrm{ha}^{-1}$ of Fe \\
\hline $80 \% \mathrm{Zn}+20 \% \mathrm{Fe}_{5.5}$ & $1.04 \mathrm{~kg} \mathrm{ha}^{-1}$ of $\mathrm{Zn}+0.22 \mathrm{~kg} \mathrm{ha}^{-1}$ of Fe \\
\hline $60 \% \mathrm{Zn}+40 \% \mathrm{Fe}_{13}$ & $1.80 \mathrm{~kg} \mathrm{ha}^{-1}$ of $\mathrm{Zn}+1.04 \mathrm{~kg} \mathrm{ha}^{-1}$ of $\mathrm{Fe}$ \\
\hline $60 \% \mathrm{Zn}+40 \% \mathrm{Fe}_{9.5}$ & $1.32 \mathrm{~kg} \mathrm{ha}^{-1}$ of $\mathrm{Zn}+0.76 \mathrm{~kg} \mathrm{ha}^{-1}$ of $\mathrm{Fe}$ \\
\hline $60 \% \mathrm{Zn}+40 \% \mathrm{Fe}_{5.5}$ & $0.78 \mathrm{~kg} \mathrm{ha}^{-1}$ of $\mathrm{Zn}+0.44 \mathrm{~kg} \mathrm{ha}^{-1}$ of Fe \\
\hline $40 \% \mathrm{Zn}+60 \% \mathrm{Fe}_{13}$ & $1.20 \mathrm{~kg} \mathrm{ha}^{-1}$ of $\mathrm{Zn}+1.56 \mathrm{~kg} \mathrm{ha}^{-1}$ of Fe \\
\hline $40 \% \mathrm{Zn}+60 \% \mathrm{Fe}_{9.5}$ & $0.88 \mathrm{~kg} \mathrm{ha}^{-1}$ of $\mathrm{Zn}+1.14 \mathrm{~kg} \mathrm{ha}^{-1}$ of $\mathrm{Fe}$ \\
\hline $40 \% \mathrm{Zn}+60 \% \mathrm{Fe}_{5.5}$ & $0.52 \mathrm{~kg} \mathrm{ha}^{-1}$ of $\mathrm{Zn}+0.66 \mathrm{~kg} \mathrm{ha}^{-1}$ of Fe \\
\hline $20 \% \mathrm{Zn}+80 \% \mathrm{Fe}_{13}$ & $0.60 \mathrm{~kg} \mathrm{ha}^{-1}$ of $\mathrm{Zn}+2.08 \mathrm{~kg} \mathrm{ha}^{-1}$ of Fe \\
\hline $20 \% \mathrm{Zn}+80 \% \mathrm{Fe}_{9.5}$ & $0.44 \mathrm{~kg} \mathrm{ha}^{-1}$ of $\mathrm{Zn}+1.52 \mathrm{~kg} \mathrm{ha}^{-1}$ of Fe \\
\hline $20 \% \mathrm{Zn}+80 \% \mathrm{Fe}_{5.5}$ & $0.26 \mathrm{~kg} \mathrm{ha}^{-1}$ of $\mathrm{Zn}+0.88 \mathrm{~kg} \mathrm{ha}^{-1}$ of $\mathrm{Fe}$ \\
\hline $100 \% \mathrm{Fe}_{13}$ & $2.6 \mathrm{~kg} \mathrm{ha}^{-1}$ of $\mathrm{Fe}$ \\
\hline $100 \% \mathrm{Fe}_{9.5}$ & $1.9 \mathrm{~kg} \mathrm{ha}^{-1}$ of $\mathrm{Fe}$ \\
\hline $100 \% \mathrm{Fe}_{5.5}$ & $1.1 \mathrm{~kg} \mathrm{ha}^{-1}$ of $\mathrm{Fe}$ \\
\hline Control & $0 \mathrm{~kg} \mathrm{ha}^{-1}$ of $\mathrm{Zn}+0 \mathrm{~kg} \mathrm{ha}^{-1}$ of $\mathrm{Fe}$ \\
\hline
\end{tabular}

The main plots received treatments of different fertilizer ratios of combined or non-combined solutions of $\mathrm{Zn}$ and $\mathrm{Fe}$, used as $\mathrm{ZnSO}_{4} .7 \mathrm{H}_{2} \mathrm{O}$ and $\mathrm{FeSO}_{4} .7 \mathrm{H}_{2} \mathrm{O}$, respectively as follows: (1) $100 \% \mathrm{Zn},(2) 80 \% \mathrm{Zn}+20 \% \mathrm{Fe}$, (3) $60 \% \mathrm{Zn}+40 \% \mathrm{Fe}$, (4) $40 \% \mathrm{Zn}+60 \% \mathrm{Fe}$, (5) $20 \% \mathrm{Zn}+80 \% \mathrm{Fe}$, (6) $100 \% \mathrm{Fe}$. Every main plot had sub-plot treatments that received fertilizer quantities of $0.5 \%(\mathrm{w} / \mathrm{v})$ as follows: $13 \mathrm{~kg}, 9.5 \mathrm{~kg}$, $5.5 \mathrm{~kg}$ and $0 \mathrm{~kg} \mathrm{ha}^{-1}$ of $\mathrm{ZnSO}_{4} .7 \mathrm{H}_{2} \mathrm{O}$ and $\mathrm{FeSO}_{4} .7 \mathrm{H}_{2} \mathrm{O}$. 


\subsection{Sampling Procedures and Analysis}

When grains reached physiological maturity, wheat plants were harvested in a $2 \mathrm{~m}^{2}$ area $(2 \mathrm{~m}$ $\times 1 \mathrm{~m})$ in the center of each plot. After harvesting and threshing, cleaned grains were weighed with an electronic scale and converted to grain yield in $\mathrm{kg} \mathrm{ha}^{-1}$. In addition, thousand kernel weight (TKW) was determined using the same electronic scale. From the harvested samples, 15 spikes were taken from each plot to determine spike length, and the grain number per spike. After washing with deionized water and re-drying up to $13 \%$ moisture content [54], whole grains were milled into flour to determine crude fat, crude fiber, crude protein, and $\mathrm{Zn}$ and Fe concentration.

In the laboratory, crude protein content was determined by the Kjeldahl procedure using a K9840 Kjeldahl Analyzer (Hanon Shandong Scientific Instruments Co., Ltd., Jinan, Shandong, China) [55]. The process involved 3 major steps: First, the sample was digested in boiling concentrated $\mathrm{H}_{2} \mathrm{SO}_{4}$ at $380{ }^{\circ} \mathrm{C}$ for $90 \mathrm{~min}$, with the addition of a catalyst, until complete dissolution and oxidation. The nitrogen was transformed into ammonium sulfate. Then, distillation was done by adding an excess of $\mathrm{NaOH}$ solution (lye). Finally, the ammonia was determined with a volumetric acid solution or by back titration. Crude protein content was obtained by multiplying total $\mathrm{N}$ by a factor of 5.70 [56].

Crude fiber analysis was done according to the filter bag technique [57] adapted to the F10 Crude Fiber Analyzer. It determines the organic residue remaining after digestion with $0.255 \mathrm{~N} \mathrm{H}_{2} \mathrm{SO}_{4}$ and $0.313 \mathrm{~N} \mathrm{NaOH}$. Approximately $1 \mathrm{~g}$ was packed and sealed into filter bags marked with an acid-resistant marker. The bags were soaked in petroleum ether for $10 \mathrm{~min}$ to extract fat from the samples. Secondary bags were attached to a sample holder for $40 \mathrm{~min}$ of heat and agitation at $100{ }^{\circ} \mathrm{C}$ in $0.255 \mathrm{~N} \mathrm{H}_{2} \mathrm{SO}_{4}$ and $0.313 \mathrm{~N} \mathrm{NaOH}$ solutions consecutively in the vessel. After acid and base heating, the solutions were exhausted and samples were washed three times with water at the same temperature for $5 \mathrm{~min}$. Then after heat and agitation in acid and base solutions, samples were are dried in an oven at $125^{\circ} \mathrm{C}$ for $2 \mathrm{~h}$, and ashed for $2 \mathrm{~h}$ at $600 \pm 15^{\circ} \mathrm{C}$. Finally, the samples were weighed to calculate the crude fiber percentage:

$$
\% \text { crude fiber }=\frac{(z-(x \times 0.992)) \times 100}{y}
$$

where $x$ is the bag weight, $y$ is the sample weight, $z$ is the loss of weight on ignition of bag/sample, and 0.992 is the blank bag ash correction.

Crude fat was analyzed using Soxhlet extraction, submerging samples in boiling solvent (petroleum ether of $30-60{ }^{\circ} \mathrm{C}$ of boiling range) that dissolves fats, oils, pigments, and other soluble substances, collectively termed "crude fat". The continuous flow of condensed solvent extracts solubilized extractables, and the resulting crude fat residue was determined gravimetrically after drying [58]. Crude fat was calculated by the following formula:

$$
\% \text { Crude fat }=\frac{F-T}{S} \times 100
$$

where $F$ is weight of the used cup + fat residue, $T$ is the weight of the empty cup, and $S$ is the test portion weight.

Zinc and Fe concentrations were determined using atomic absorption spectrometry (AA320CRT; Shanghai Analytical Instrument Overall Factory, Shanghai, China) [59]. Every material was soaked in nitric acid and washed with deionized water before being used, to avoid any contamination. Dry grain samples were ground with a mixer mill (MM400, Retsch, GmbH, Haan, Germany). Samples in crucibles were put over a hotplate until smoking ceased before being placed into a furnace and incinerated at $550{ }^{\circ} \mathrm{C}$ for $6 \mathrm{~h}$. After cooling, the ash was dissolved in $5 \mathrm{ml}$ 1:1 (v:v) $\mathrm{HNO}_{3}$, and the inner wall of the container was washed, then transferred to a $50 \mathrm{ml}$ volumetric flask with deionized water. Finally, the test solution was directly measured by atomic absorption spectrometry.

The instrument parameters were as follows: Wavelength, $213.9 \mathrm{~nm}$ and $248.3 \mathrm{~nm}$ for $\mathrm{Zn}$ and $\mathrm{Fe}$, respectively; sit width, $1.3 \mathrm{~nm}$ for $\mathrm{Zn}$ and $0.2 \mathrm{~nm}$ for Fe; lamp current, $5 \mathrm{~mA}$ for $\mathrm{Zn}$ and $12.5 \mathrm{~mA}$ 
for Fe; photomultiplier tube negative high voltage, $349 \mathrm{~V}$ for $\mathrm{Zn}$ and $435 \mathrm{~V}$ for Fe. The analysis conditions were as follows: Type of flame, air- $\mathrm{C}_{2} \mathrm{H}_{2}$; gas flow rate, $1.8 \mathrm{~L} \mathrm{~min}^{-1}$; gas pressure, $160 \mathrm{kPa}$; burner height, $7.5 \mathrm{~mm}$; delay time, $2 \mathrm{~s}$ and data collection time, $1 \mathrm{~s}$. The limit of detection (LOD) and limit of quantification (LOQ) were calculated for Fe and $\mathrm{Zn}$ concentration by multiplying the standard deviation by 3 (LOD) and by 10 (LOQ), and dividing by the slope of the analytical curve. The concentration of samples was higher than LOD and LOQ. To evaluate the trueness and precision of the analytical method, spike tests were performed, as there was no access to certified references. The relative standard deviation values were both below $10 \%$, and the recovery percentages were $103.4 \%$ and $99.7 \%$ for $\mathrm{Zn}$ and Fe, respectively. LOD was 0.10 and $0.19 \mathrm{mg} \mathrm{kg}^{-1}$ and LOQ was 0.31 and $0.58 \mathrm{mg}$ $\mathrm{kg}^{-1}$ for $\mathrm{Zn}$ and $\mathrm{Fe}$, respectively.

\subsection{Statistical Analysis}

Data were subjected to the analysis of covariance (ANCOVA) of the effect of $\mathrm{Zn}$ and Fe fertilizer ratio and quantity and their interactions. Means comparisons were done by a two-sided Dunnett's test, comparing all means against the control using PASW Statistics 18 software. Graphs were made using the PASW Statistics 18 software and Excel 2016.

\section{Results}

Grain yield was not significantly affected by cropping year, nor its interaction with fertilizer ratio and fertilizer quantity, while however, fertilizer ratio and its interaction with fertilizer quantity significantly affected grain yield, TKW, spike length, crude protein, $\mathrm{Zn}$ content, and Fe content. That the fertilizer quantity affected spike length, crude fiber and the $\mathrm{Zn}$ content is shown in Table 2. Crude fiber was affected only by fertilizer quantity. The interaction of cropping year, fertilizer ratio, and fertilizer quantity did not have a significant impact on all studied variables (Table 2). The following tables separate cropping years to see the effect of fertilizer ratio and fertilizer quantity clearly. The detailed table of analysis of covariance of the effects of experimental factors and their interactions on grain yield, TKW, spike length and kernels per spike are presented in supplementary materials Table S1.

Table 2. Analysis of covariance (ANCOVA) of the effects of fertilizer ratio and quantity and their interactions on grain yield, thousand kernel weight (TKW), spike length, kernels per spike, crude fat, crude fiber, crude protein, $\mathrm{Zn}$ content and Fe in 2 cropping seasons.

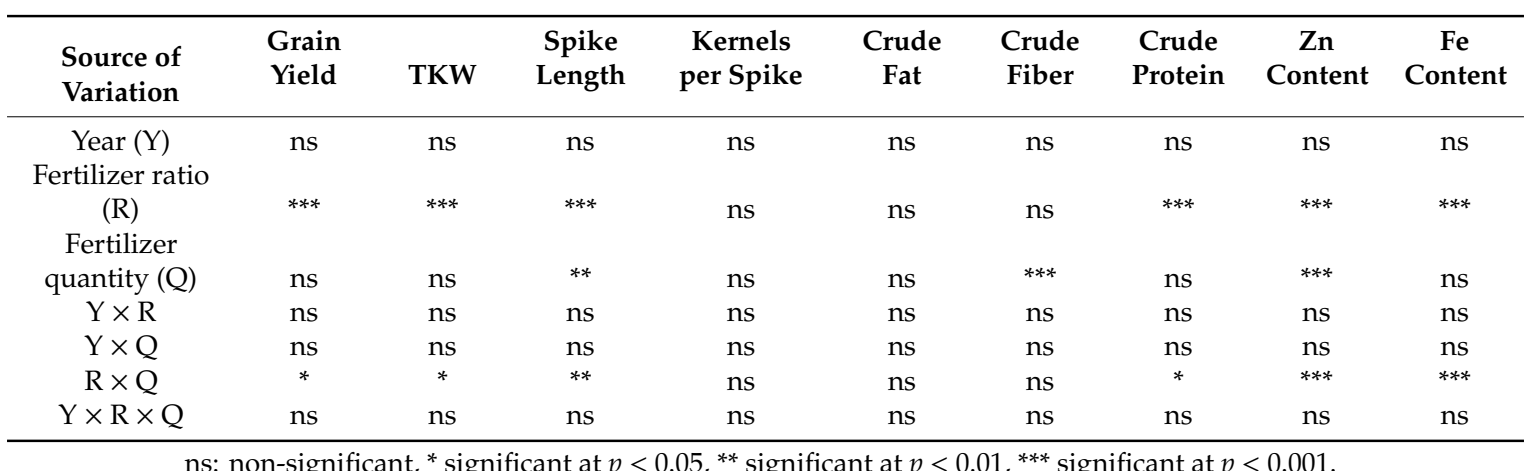

Compared with the control, during the first cropping season (2016-2017), 100\% $\mathrm{Fe}_{13}$ treatment influenced grain yield, while in the second cropping season (2017-2018), different Zn and Fe treatments, either mixed or not, affected the yield. In addition, treatments containing high Fe content significantly increased the yield, i.e., solutions with Fe content $\geq 60 \%$, especially $100 \% \mathrm{Fe}_{13}$, followed by $20 \% \mathrm{Zn}$ $+80 \% \mathrm{Fe}_{5.5}$ with $61.59 \%$ and $39.19 \%$ increases, respectively, in the first cropping year. In the second cropping season, $100 \% \mathrm{Fe}_{13}$ still outperformed, followed by $40 \% \mathrm{Zn}+60 \% \mathrm{Fe}_{5.5}$ with $63.90 \%$ and $41.21 \%$ increases, respectively (Table 3 ). 
Averaged across the two cropping seasons, $100 \% \mathrm{Fe}_{13}$ outweighs, followed by $20 \% \mathrm{Zn}+80 \% \mathrm{Fe}_{5.5}$, while the lowest yield was observed with $80 \% \mathrm{Zn}+20 \% \mathrm{Fe}_{9.5}$, with a significant negative effect on yield (Figure 2). One can observe that Fe tends to increase yield more than $\mathrm{Zn}$ does. Generally, foliar application of $\mathrm{Zn}$ and Fe fertilizers showed significant effects in the second year over the first year. It was observed that yield was increased proportionally with the quantity of $100 \%$ Fe fertilizer as follows: $100 \% \mathrm{Fe}_{13}>100 \% \mathrm{Fe}_{9.5}>100 \% \mathrm{Fe}_{5.5}$. Ratio $80 \% \mathrm{Zn}+20 \% \mathrm{Fe}$ and $60 \% \mathrm{Zn}+40 \% \mathrm{Fe}$ presented relatively the same effects, which had no statistically significant effect over the control. Ratio $40 \% \mathrm{Zn}+$ $60 \% \mathrm{Fe}$ and $20 \% \mathrm{Zn}+80 \%$ Fe showed almost the same influence on the yield, and their effect was better than that of $80 \% \mathrm{Zn}+20 \% \mathrm{Fe}$ and $60 \% \mathrm{Zn}+40 \% \mathrm{Fe}$. According to quantities, $5.5 \mathrm{~kg}$ presented higher yield, while $9.5 \mathrm{~kg}$ had lower yield in both ratios.

Table 3. Grain yield, thousand kernel weight (TKW), spike length and kernels per spike means comparison against control, as affected by foliar application of $\mathrm{Zn}$ and Fe fertilizers ${ }^{\mathrm{a}}$.

\begin{tabular}{|c|c|c|c|c|c|c|c|c|}
\hline Treatments $^{b}$ & \multicolumn{4}{|c|}{ 2016-2017 } & \multicolumn{4}{|c|}{ 2017-2018 } \\
\hline $100 \% \mathrm{Zn}_{13}$ & 4.228 & 44.07 & 7.88 & 35.20 & $4.106^{* * *}$ & $44.20 *$ & $7.91 * * *$ & 35.21 \\
\hline $100 \% \mathrm{Zn}_{9.5}$ & 3.829 & 43.96 & 7.79 & 38.85 & $3.800 * * *$ & 44.08 & $7.83^{* * *}$ & $38.38^{* * *}$ \\
\hline $100 \% \mathrm{Zn}_{5.5}$ & 3.711 & $46.15^{*}$ & 8.35 & 38.85 & $3.590 * *$ & $46.01 * * *$ & 8.32 & $38.72 * * *$ \\
\hline $80 \% \mathrm{Zn}+20 \% \mathrm{Fe}_{9.5}$ & 2.785 & 43.62 & 8.43 & 36.75 & $2.682 *$ & 43.51 & $8.44^{* *}$ & $36.62 *$ \\
\hline $80 \% \mathrm{Zn}+20 \% \mathrm{Fe}_{5.5}$ & 3.332 & 44.25 & 8.49 & 40.10 & 3.361 & 44.08 & $8.43^{* *}$ & $39.84^{* * *}$ \\
\hline $60 \% \mathrm{Zn}+40 \% \mathrm{Fe}_{13}$ & 2.919 & 43.01 & 8.04 & 35.55 & 2.869 & 42.74 & $7.98^{* *}$ & 34.99 \\
\hline $60 \% \mathrm{Zn}+40 \% \mathrm{Fe}_{9.5}$ & 2.905 & 42.68 & 7.86 & 34.25 & 3.007 & 42.71 & $7.94^{* *}$ & 34.63 \\
\hline $60 \% \mathrm{Zn}+40 \% \mathrm{Fe}_{5.5}$ & 3.157 & 43.28 & 8.03 & 34.85 & 3.064 & 43.32 & $7.92 * * *$ & 34.21 \\
\hline $40 \% \mathrm{Zn}+60 \% \mathrm{Fe}_{13}$ & 4.051 & 41.68 & 8.01 & 38.00 & $3.955^{* * *}$ & $41.46^{* *}$ & $7.94 * *$ & $37.78^{* * *}$ \\
\hline $20 \% \mathrm{Zn}+80 \% \mathrm{Fe}_{9.5}$ & 3.685 & 41.81 & 8.65 & 36.05 & $3.805^{* * *}$ & $41.80^{* *}$ & $8.63^{* * *}$ & $36.49 *$ \\
\hline $20 \% \mathrm{Zn}+80 \% \mathrm{Fe}_{5.5}$ & 4.251 & 43.76 & 8.39 & 39.85 & $4.316^{* * *}$ & 43.55 & $8.38 *$ & $39.29^{* * *}$ \\
\hline $100 \% \mathrm{Fe}_{13}$ & $4.935^{*}$ & 43.61 & 8.18 & 36.85 & $5.050 * * *$ & 43.76 & 8.09 & $37.13^{* *}$ \\
\hline $100 \% \mathrm{Fe}_{9.5}$ & 4.228 & 41.21 & 8.55 & 36.40 & $4.037^{* * *}$ & $41.03^{* * *}$ & $8.56^{* * *}$ & 35.94 \\
\hline $100 \% \mathrm{Fe}_{5.5}$ & 3.941 & 44.16 & 8.22 & 37.65 & $4.022 * * *$ & $44.26 *$ & 8.17 & $37.28 * * *$ \\
\hline Control & 3.054 & 43.07 & 8.19 & 35.67 & 3.081 & 43.02 & 8.19 & 35.15 \\
\hline
\end{tabular}

${ }^{\mathrm{a}}$ : Values are means of three replicates. ${ }^{\mathrm{b}}$ : Combination of $\mathrm{Zn}$ and Fe fertilizers described in Table 1. Sprayed three times, ${ }^{*}$ significant at $p<0.05,{ }^{* *}$ significant at $p<0.01,{ }^{* * *}$ significant at $p<0.001$

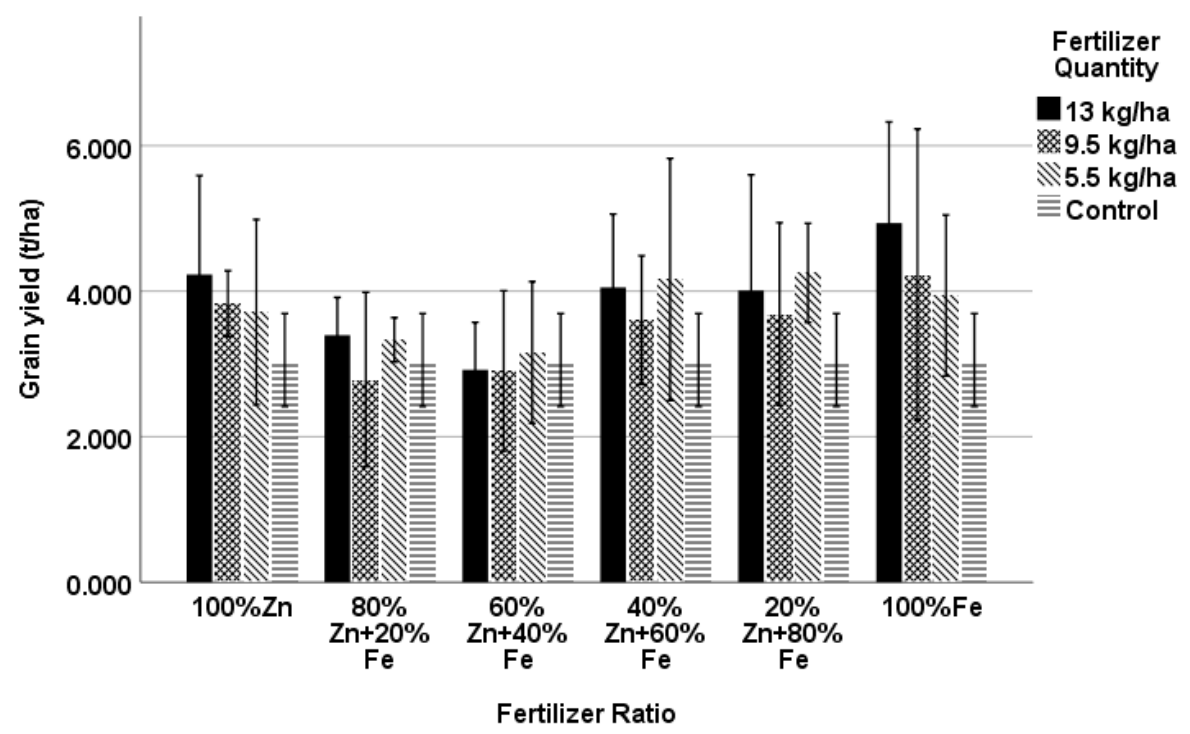

Figure 2. Effect of combined foliar application of Zn and Fe on yield of winter wheat (Nongda 399 cultivar). Values are means of two cropping seasons. Vertical bars represent the $95 \%$ confidence interval. 
Largely, the data revealed that TKW was not affected by foliar application in the first year, with the exception of $100 \% \mathrm{Zn}_{5.5}$, which increased TKW significantly, whereas, in the second year, the treatments showed better performance, with $100 \% \mathrm{Zn}_{13}, 100 \% \mathrm{Zn}_{5.5}$, and $100 \% \mathrm{Fe}_{5.5}$ increasing TKW by $2 \%, 7 \%$ and $3 \%$, respectively. Other treatments i.e., $40 \% \mathrm{Zn}+60 \% \mathrm{Fe}_{13}, 20 \% \mathrm{Zn}+80 \% \mathrm{Fe}_{13}, 20 \% \mathrm{Zn}$ $+80 \% \mathrm{Fe}_{9.5}$, and $100 \% \mathrm{Fe}_{9.5}$, significantly decreased TKW by $3 \%, 5 \%$, 2\%, and $4 \%$, respectively (Table 3 ).

Compared to other fertilizer ratios, 100\% $\mathrm{Zn}$ and $60 \% \mathrm{Zn}+40 \%$ Fe decreased spike length significantly, while $20 \% \mathrm{Zn}+80 \%$ Fe and $100 \%$ Fe increased spike length significantly in most fertilizer quantities in the second season (Table 3). The number of kernels per spike was not considerably affected in the first year, but was significantly increased in the second year by a number of treatments: Some of them were significant at $0.001,0.01$ and 0.05 . Furthermore, $80 \% \mathrm{Zn}+20 \% \mathrm{Fe}_{5.5}$ showed a $13 \%$ increase followed by $20 \% \mathrm{Zn}+80 \% \mathrm{Fe}_{5.5}$ which increased by $11 \%$. It is important to note that all levels of $60 \% \mathrm{Zn}+40 \%$ Fe did not significantly affect the number of kernels per spike (Table 3).

Throughout the two years, the foliar application of $\mathrm{Zn}$ and Fe fertilizers did not considerably affect crude fat for all treatments (Table 4). The average means of treatments of those two years are plotted in Figure 3 a.

Crude fiber content was significantly increased by a foliar application of $\mathrm{Zn}$ and Fe fertilizers in all treatments, but most remarkably up to three-fold with the $60 \% \mathrm{Zn}+40 \% \mathrm{Fe}_{5.5}$ treatment. Moreover, $80 \% \mathrm{Zn}+20 \% \mathrm{Fe}$ and $60 \% \mathrm{Zn}+40 \%$ Fe fertilizer ratios have outweighed other ratios; even though most ratios were statistically significant, but $80 \% \mathrm{Zn}+20 \% \mathrm{Fe}$ and $60 \% \mathrm{Zn}+40 \%$ Fe values were higher (Figure 3c). In addition, some treatments were not statistically significantly different from the control: $100 \% \mathrm{Zn}_{9.5}, 40 \% \mathrm{Zn}+60 \% \mathrm{Fe}_{5.5}$, and $20 \% \mathrm{Zn}+80 \% \mathrm{Fe}_{13}$ in both years. The lowest value was observed in the control treatment (Table 4).

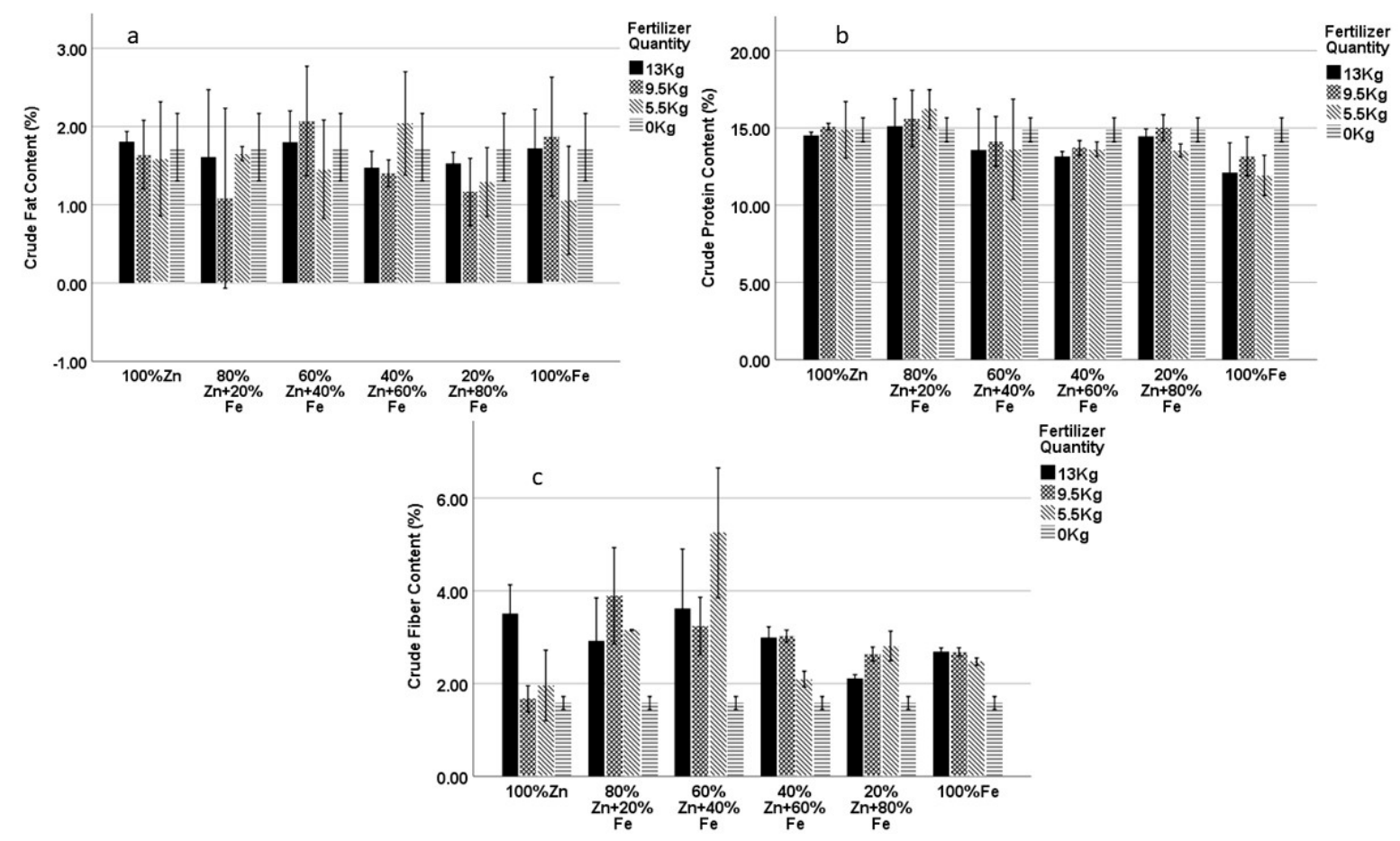

Figure 3. Crude fat (a), crude protein (b), and crude fiber (c) content in wheat grains as affected by foliar application of combined $\mathrm{Zn}$ and Fe fertilizers. Plotted values are means of two cropping seasons. Vertical bars represent the $95 \%$ confidence interval. 
Table 4. Means comparison of crude fat, crude fiber, and crude protein of whole grain winter wheat affected by foliar application of $\mathrm{Zn}$ and Fe fertilizers ${ }^{\mathrm{a}}$.

\begin{tabular}{|c|c|c|c|c|c|c|}
\hline \multirow[b]{2}{*}{ Treatments $\mathbf{b}$} & \multicolumn{3}{|c|}{ 2016-2017 } & \multicolumn{3}{|c|}{ 2017-2018 } \\
\hline & $\begin{array}{c}\text { Crude Fat } \\
(\%)\end{array}$ & $\begin{array}{c}\text { Crude Fiber } \\
(\%)\end{array}$ & $\begin{array}{c}\text { Crude } \\
\text { Protein (\%) }\end{array}$ & $\begin{array}{c}\text { Crude Fat } \\
(\%)\end{array}$ & $\begin{array}{c}\text { Crude Fiber } \\
(\%)\end{array}$ & $\begin{array}{c}\text { Crude } \\
\text { Protein (\%) }\end{array}$ \\
\hline $100 \% \mathrm{Zn}_{13}$ & 1.80 & $3.51^{* * *}$ & 14.51 & 1.80 & $3.58^{* * *}$ & 14.49 \\
\hline $100 \% \mathrm{Zn}_{9.5}$ & 1.64 & 1.67 & 15.08 & 1.88 & 1.77 & 15.09 \\
\hline $100 \% \mathrm{Zn}_{5.5}$ & 1.58 & $1.96^{* * *}$ & 14.87 & 1.78 & 2.17 & 14.99 \\
\hline $80 \% \mathrm{Zn}+20 \% \mathrm{Fe}_{13}$ & 1.61 & $2.92 * * *$ & 15.11 & 1.71 & $2.96^{* * *}$ & 15.00 \\
\hline $80 \% \mathrm{Zn}+20 \% \mathrm{Fe}_{9.5}$ & 1.08 & $3.89 * * *$ & 15.60 & 1.46 & $4.13^{* * *}$ & $15.49 *$ \\
\hline $80 \% \mathrm{Zn}+20 \% \mathrm{Fe}_{5.5}$ & 1.65 & $3.15^{* * *}$ & 16.21 & 1.95 & $3.29 * * *$ & $16.28 * * *$ \\
\hline $60 \% \mathrm{Zn}+40 \% \mathrm{Fe}_{13}$ & 1.80 & $3.62 * * *$ & 13.57 & 2.07 & $3.63^{* * *}$ & $13.40^{* *}$ \\
\hline $60 \% \mathrm{Zn}+40 \% \mathrm{Fe}_{9.5}$ & 2.07 & $3.24^{* * *}$ & 14.12 & 2.02 & $3.31^{* * *}$ & 14.21 \\
\hline $60 \% \mathrm{Zn}+40 \% \mathrm{Fe}_{5.5}$ & 1.45 & $5.25 * * *$ & 13.62 & 1.86 & $5.53 * * *$ & $13.41^{* *}$ \\
\hline $40 \% \mathrm{Zn}+60 \% \mathrm{Fe}_{13}$ & 1.47 & $2.99 * * *$ & 13.15 & 1.57 & $3.15^{* * *}$ & $13.17^{* * *}$ \\
\hline $40 \% \mathrm{Zn}+60 \% \mathrm{Fe}_{9.5}$ & 1.40 & $3.02 * * *$ & 13.70 & 1.93 & $3.17^{* * *}$ & $13.72 *$ \\
\hline $40 \% \mathrm{Zn}+60 \% \mathrm{Fe}_{5.5}$ & 2.04 & 2.09 & 13.62 & 2.37 & 2.25 & $13.59 *$ \\
\hline $20 \% \mathrm{Zn}+80 \% \mathrm{Fe}_{13}$ & 1.53 & 2.11 & 14.45 & 1.86 & 2.26 & 14.42 \\
\hline $20 \% \mathrm{Zn}+80 \% \mathrm{Fe}_{9.5}$ & 1.16 & $2.63^{* *}$ & 15.01 & 1.35 & $2.75^{* * *}$ & 15.05 \\
\hline $20 \% \mathrm{Zn}+80 \% \mathrm{Fe}_{5.5}$ & 1.29 & $2.81^{* * *}$ & 13.54 & 1.75 & $2.91^{* * *}$ & $13.51^{* *}$ \\
\hline $100 \% \mathrm{Fe}_{13}$ & 1.72 & $2.69 * *$ & $12.10^{* *}$ & 1.90 & $2.82 * * *$ & $11.98^{* * *}$ \\
\hline $100 \% \mathrm{Fe}_{9.5}$ & 1.87 & $2.68^{* *}$ & 13.15 & 1.98 & $2.81 * * *$ & $13.07^{* * *}$ \\
\hline $100 \% \mathrm{Fe}_{5.5}$ & 1.05 & $2.47 *$ & $11.92 * * *$ & 1.16 & $2.61 * *$ & $11.84^{* * *}$ \\
\hline Control & 1.73 & 1.58 & 14.87 & 2.14 & 1.70 & 14.57 \\
\hline
\end{tabular}

${ }^{a}$ : Values are means of three replicates. ${ }^{b}$ : Combination of $\mathrm{Zn}$ and Fe fertilizers described in Table 1. Sprayed three times, ${ }^{*}$ significant at $p<0.05,{ }^{* * *}$ significant at $p<0.01,{ }^{* * *}$ significant at $p<0.001$.

Results show that crude protein was significantly improved by foliar application of $\mathrm{Zn}$ and Fe fertilizers only in the second year in the $80 \% \mathrm{Zn}+20 \% \mathrm{Fe}_{9.5}$ and $80 \% \mathrm{Zn}+20 \% \mathrm{Fe}_{5.5}$ treatment by $6 \%$ and $12 \%$, respectively. Specifically, $80 \% \mathrm{Zn}+20 \% \mathrm{Fe}_{5.5}$ was the outstanding treatment in increasing crude protein. Treatments consisting of $\mathrm{Zn}$ only $100 \% \mathrm{Zn}_{13}, 100 \% \mathrm{Zn}_{9.5}$ and $100 \% \mathrm{Zn}_{5.5}$ did not considerably affect the crude protein content of whole grain. Treatments containing Fe only $100 \% \mathrm{Fe}_{13}$, $100 \% \mathrm{Fe}_{9.5}, 100 \% \mathrm{Fe}_{5.5}$ significantly reduced crude protein content up to $13 \%$ with $100 \% \mathrm{Fe}_{5.5}$, and this value was the lowest among treatments. Treatments of $60 \% \mathrm{Zn}+40 \% \mathrm{Fe}, 40 \% \mathrm{Zn}+60 \%$ Fe and $20 \%$ $\mathrm{Zn}+80 \%$ Fe fertilizer ratios, either did not significantly increase crude protein content or rather it decreased crude protein content (Table 4). Fertilizer ratio $60 \% \mathrm{Zn}+40 \% \mathrm{Fe}$ and $40 \% \mathrm{Zn}+60 \%$ Fe in their respective quantities showed almost the same effect upon crude protein, which is better than that of $100 \% \mathrm{Fe}$, but not as good as that of $100 \% \mathrm{Zn}, 80 \% \mathrm{Zn}+20 \% \mathrm{Fe}$ and $20 \% \mathrm{Zn}+80 \% \mathrm{Fe}$. Averaged across these two years, the plotted means shows that treatments of the $100 \%$ Fe ratio had the lowest crude protein content, while those of the $80 \% \mathrm{Zn}+20 \%$ Fe ratio presented the highest values (Figure $3 \mathrm{~b}$ ). The table of analysis of covariance of the effects of experimental factors and their interactions on crude fat, crude fiber and crude protein are presented in Table S2 of supplementary materials.

The concentration of $\mathrm{Zn}$ in grain was significantly influenced by foliar application of $\mathrm{Zn}$ and Fe fertilizers in both years (Table 5). The average of grain $\mathrm{Zn}$ concentration increased from $19.79 \mathrm{mg} \mathrm{kg}^{-1}$ in the control to $38.79 \mathrm{mg} \mathrm{kg}^{-1}$ in the $100 \% \mathrm{Zn}_{9.5}$ treatment during the first year, and from $19.25 \mathrm{mg} \mathrm{kg}^{-1}$ in the control to $39.63 \mathrm{mg} \mathrm{kg}^{-1}$ in the $100 \% \mathrm{Zn}_{9.5}$ treatment in the second year, which is an increment of $96.9 \%$ and $105.8 \%$, respectively. The highest increase was observed in treatments with only $\mathrm{Zn}$ or a high $\mathrm{Zn}$ fertilizer ratio particularly in $100 \% \mathrm{Zn}_{9.5}$, and the lowest increase was found in treatments with low or no $\mathrm{Zn}$. The lowest $\mathrm{Zn}$ concentration was observed in the $100 \% \mathrm{Fe}_{13}$ treatment during the two years (Table 5). Zinc mean values of the two seasons show that when $\mathrm{Zn}$ concentration in sprayed solution decreased, it tended to decrease the grain $Z n$ concentration. Hence, the $100 \%$ Fe ratio shows the smallest values of $\mathrm{Zn}$ concentration compared to other ratios, while 100\% $\mathrm{Zn}$ shows higher $\mathrm{Zn}$ concentration values (Figure 4). 
Table 5. Means comparison of $\mathrm{Zn}$ and Fe content of whole grain winter wheat affected by foliar application of $\mathrm{Zn}$ and Fe fertilizers ${ }^{\mathrm{a}}$.

\begin{tabular}{|c|c|c|c|c|}
\hline \multirow{2}{*}{ Treatments $b$} & \multicolumn{2}{|c|}{ 2016-2017 } & \multicolumn{2}{|c|}{ 2017-2018 } \\
\hline & $\mathrm{Zn}\left(\mathrm{mg} \mathrm{kg}^{-1}\right)^{\mathrm{c}}$ & $\mathrm{Fe}\left(\mathrm{mg} \mathrm{kg} \mathrm{kg}^{-1}\right)$ & Zn (mg kg $\left.{ }^{-1}\right)$ & $\mathrm{Fe}\left(\mathrm{mg} \mathrm{kg}{ }^{-1}\right)$ \\
\hline $100 \% \mathrm{Zn}_{13}$ & $37.74^{* * *}$ & 36.34 & $37.46^{* * *}$ & 35.91 \\
\hline $100 \% Z_{9.5}$ & $38.79^{* * *}$ & 43.22 & $39.63 * * *$ & $43.02 * * *$ \\
\hline $100 \% \mathrm{Zn}_{5.5}$ & $35.12 * * *$ & $49.26^{* *}$ & $34.17 * * *$ & $48.32 * * *$ \\
\hline $80 \% \mathrm{Zn}+20 \% \mathrm{Fe}_{13}$ & 25.75 & 41.52 & $27.08^{* * *}$ & 40.90 * \\
\hline $80 \% \mathrm{Zn}+20 \% \mathrm{Fe}_{9.5}$ & $29.97 *$ & $46.32 *$ & $30.64^{* * *}$ & $46.87^{* * *}$ \\
\hline $80 \% \mathrm{Zn}+20 \% \mathrm{Fe}_{5.5}$ & 26.04 & 44.14 & $26.12 * * *$ & $45.00 * * *$ \\
\hline $60 \% \mathrm{Zn}+40 \% \mathrm{Fe}_{13}$ & $32.52 * *$ & 42.27 & $32.51 * * *$ & $41.40 * *$ \\
\hline $60 \% \mathrm{Zn}+40 \% \mathrm{Fe}_{9.5}$ & 27.90 & 42.30 & $26.72 * * *$ & $41.45^{* * *}$ \\
\hline $60 \% \mathrm{Zn}+40 \% \mathrm{Fe}_{5.5}$ & 26.12 & 43.83 & $25.49 * * *$ & $42.27^{* * *}$ \\
\hline $40 \% \mathrm{Zn}+60 \% \mathrm{Fe}_{13}$ & 26.54 & 43.10 & $26.74^{* * *}$ & $43.27^{* * *}$ \\
\hline $40 \% \mathrm{Zn}+60 \% \mathrm{Fe}_{9.5}$ & 25.78 & 42.83 & $25.44^{* * *}$ & $42.47^{* * *}$ \\
\hline $40 \% \mathrm{Zn}+60 \% \mathrm{Fe}_{5.5}$ & 23.66 & 42.27 & $22.72 * *$ & $42.10^{* * *}$ \\
\hline $20 \% \mathrm{Zn}+80 \% \mathrm{Fe}_{13}$ & 22.70 & 42.51 & $22.41 *$ & $42.41^{* * *}$ \\
\hline $20 \% \mathrm{Zn}+80 \% \mathrm{Fe}_{9.5}$ & 26.66 & 45.31 & $26.27^{* * *}$ & $45.40^{* * *}$ \\
\hline $20 \% \mathrm{Zn}+80 \% \mathrm{Fe}_{5.5}$ & 25.27 & $47.17^{*}$ & $25.04^{* * *}$ & $47.33^{* * *}$ \\
\hline $100 \% \mathrm{Fe}_{13}$ & 17.41 & $46.50 *$ & 17.10 & $46.15^{* * *}$ \\
\hline $100 \% \mathrm{Fe}_{9.5}$ & 17.99 & 44.05 & 17.49 & $44.20^{* * *}$ \\
\hline $100 \% \mathrm{Fe}_{5.5}$ & 26.84 & 43.28 & $25.15^{* * *}$ & $42.16^{* * *}$ \\
\hline Control & 19.79 & 38.41 & 19.25 & 38.18 \\
\hline
\end{tabular}

a: Values are means of three replicates plots. ${ }^{\mathrm{b}}: \mathrm{Zn}$ and Fe fertilizers applied three times; ${ }^{\mathrm{c}}: \mathrm{Zn}$ and Fe contents values are expressed in mg per $\mathrm{kg}$ of dry weight; * significant at $p<0.05$, ${ }^{* *}$ significant at $p<0.01,{ }^{* * *}$ significant at $p<0.001$.

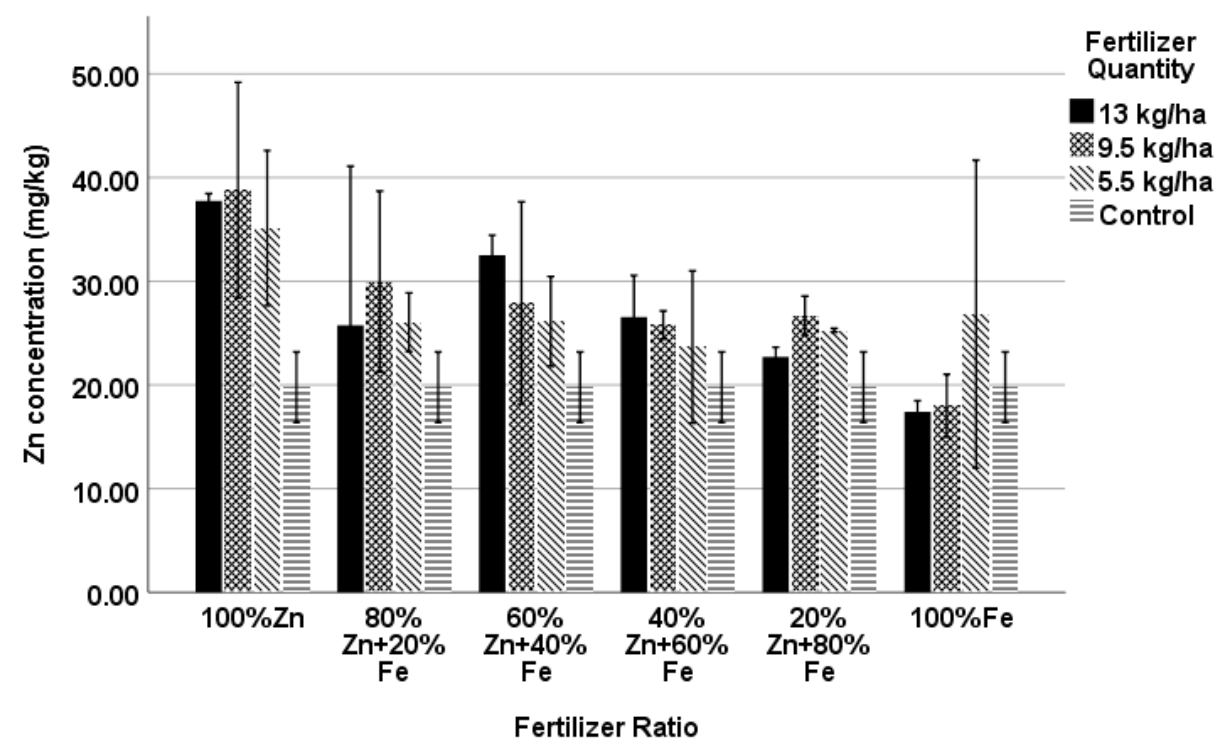

Figure 4. Effect of foliar application of combined $\mathrm{Zn}$ and Fe fertilizers on wheat grain Zn concentration. Values plotted are means of two copping seasons. Vertical bars represent the $95 \%$ confidence interval.

The concentration of Fe was significantly influenced by a foliar application of combined $\mathrm{Zn}$ and Fe fertilizers in both years, but mostly in the second year (Table 5). Average concentration of treatments compared to control in the first season shows that Fe was significantly increased in $100 \% \mathrm{Zn}_{5.5}, 80 \% \mathrm{Zn}$ $+20 \% \mathrm{Fe}_{9.5}, 20 \% \mathrm{Zn}+80 \% \mathrm{Fe}_{5.5}$ and $100 \% \mathrm{Fe}_{13}$, and the increase varied between 8 and $28 \%$, according to treatment, with the exception of $100 \% \mathrm{Zn}_{13}$, which decreased Fe concentration by 5\% (Table 5). Average Fe concentration in the second season improved from $38.18 \mathrm{mg} \mathrm{kg}^{-1}$ in control to $48.32 \mathrm{mg}$ $\mathrm{kg}^{-1}$ in $100 \% \mathrm{Zn}_{5.5}$, and its increase varies between 8.4 and $26.5 \%$ across treatments. Generally, Fe concentration was not improved by the combination of $\mathrm{Zn}$ and Fe in the first year, but an increase was 
observed in the second year. Fe applied alone significantly improved with $100 \% \mathrm{Fe}_{5.5}$ only in the first year, and in the second year, all quantities did significantly improve grain Fe concentration (Table 5). During the two seasons, $60 \% \mathrm{Zn}+40 \% \mathrm{Fe}$ and $40 \% \mathrm{Zn}+60 \%$ Fe ratios seemed to have almost the same effect on Fe grain concentration, which was a small increase compared to other ratios (Figure 5). The analysis of covariance of the effects of experimental factors and their interactions on $\mathrm{Zn}$ and Fe concentration in grain can be found in Table $\mathrm{S} 2$ of supplementary materials.

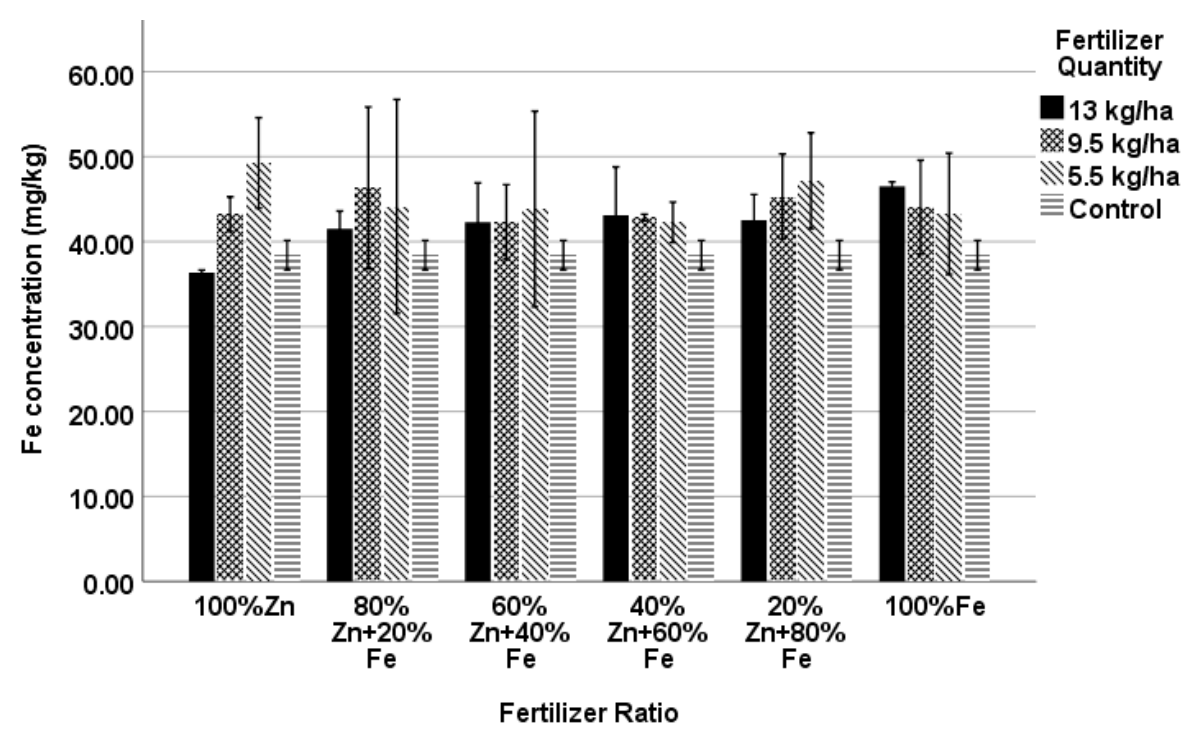

Figure 5. Concerning the foliar application of combined $\mathrm{Zn}$ and Fe fertilizers on wheat grain Fe concentration. Values plotted are the means of both copping seasons. Vertical bars represent the $95 \%$ confidence interval.

\section{Discussion}

\subsection{Yield and Yield Components}

In this study, grain yield was significantly improved by some $\mathrm{Zn}$ and Fe foliar fertilizer treatments. Not much difference was observed in the first season, but in the second season there was reasonable significance especially with $20 \% \mathrm{Zn}+80 \% \mathrm{Fe}$ and $100 \% \mathrm{Fe}$ in their respective quantities. This could be explained by the fact that the plant response to fertilization or micronutrient deficiency is greatly affected by seasonal changes in climatic conditions [60].

Compared to the control, $100 \% \mathrm{Zn}$ treatments significantly increased the grain yield in the second cropping season, even though the increase was not significant in the first cropping year. Zn was previously reported to increase grain yield [61]. The first year results correlate with those reported by Zhang et al. [62] and Li et al. [50], who argued that yield was unaffected by any application of Zn on both medium and high $\mathrm{Zn}$ and high Fe soil concentrations in China. Cakmak et al. [27] in Turkey also reported that in Samsun and Adana (medium to high DTPA-Zn soil concentration), the grain yield was unaffected by foliar application of Zn, while in Konya (low DTPA-Zn soil concentration), the grain yield was increased by $23 \%$ and $21 \%$ in two different years. The inability to affect the yield and yield components might be due to relatively high DTPA-extractable Zn and Fe concentrations in the experimental soils. In contrast, despite the high DTPA-Zn and Fe soil concentration, our study in the second years presented an increase in grain yield.

In addition, yield components resulted in biochemical reactions and a relocation of photosynthetic products [63]. It is believed that through photosynthesis and sugar transformations, Zn exerts an effect on carbohydrates metabolism [64], and Zn deficiency may result in reductions in net photosynthesis by $50-70 \%$, depending on the plant species and the severity of the deficiency, inducing dramatic changes in yield components [64]. Zinc in plants plays a major role as a functional, structural or 
regulatory co-factor of many of enzymes, and is involved in sucrose and starch formation [64,65]. High Fe concentrations $(100 \% \mathrm{Fe})$ significantly increased yield, and the best yield was observed with $100 \%$ $\mathrm{Fe}_{13}$. All of the $20 \% \mathrm{Zn}+80 \% \mathrm{Fe}$ and $40 \% \mathrm{Zn}+60 \%$ Fe treatments were also significant in increasing the yield, even though the difference over the control was more observed in the second season.

The combination of $\mathrm{Zn}$ and Fe positively affected the yield in some ratios. During this study, the yield was reduced with $80 \% \mathrm{Zn}+20 \% \mathrm{Fe}$ and $60 \% \mathrm{Zn}+40 \%$ Fe ratios, compared to the control and treatments where $\mathrm{Zn}$, Fe were not combined. It was observed that $40 \% \mathrm{Zn}+60 \% \mathrm{Fe}$ and $20 \% \mathrm{Zn}+$ $80 \%$ Fe ratios increased the yield, which is a different effect. Iron percentage up to $40 \%$ in the solution reduced the yield, but from $60 \%$, the yield increased. The increase of Fe up to $40 \%$ in the solution could have reduced or inhibited the activity and translocation of $\mathrm{Zn}$ in contributing to yield, but a higher amount of Fe actually increased grain yield [66]. The antagonism between Fe and $\mathrm{Zn}$ might be the reason for the yield decrease. Iron applied separately increased yield, and a high amount gave a higher yield. Partially, similar results were reported by Verma and Tripathi [67], who illustrated the decrease of grain and straw yield in the paddy; when $\mathrm{Zn}$ was not applied, Fe application decreased grain yield and straw, but with an addition of $\mathrm{Zn}$, Fe did not affect grain and straw. The present study showed that low a percentage of Fe in the solution reduced the yield, while higher percentages increased the yield. In addition, Fe metabolism was reported to be affected by S availability in Strategy I and Strategy II plants. For instance, Zuchi et al. argued that the uptake and translocation of Fe to the shoot might be prevented by an inadequate supply of $S$ in tomato, and the Fe deficiency led to a strong decrease in total $\mathrm{S}$ content in the shoots and roots of tomato [43]. Moreover, Ciaffi et al. demonstrated that augmenting the $\mathrm{S}$ uptake capacity of roots can maintain phytosiderophores production under Fe deficiency, and Fe deprivation resulted in a higher accumulation of $S$ in the shoots of wheat [42]. The interaction among plant nutrients can be either synergistic, antagonistic, zero-interactive or Liebig-synergistic. These interactions illustrate that the supply of one nutrient can affect the function of another nutrient [68]. Therefore, these interactions can affect plant growth and yield $[69,70]$.

\subsection{Crude Fat}

Crude fat was not significantly affected by the foliar application of $\mathrm{Zn}$ and Fe fertilizers in both cropping years. Similar results were reported by Bressani [71] when NPK 12-24-12 was applied to three amaranth species: A. eruentus (Rodale 82S-1034), A. hypochondriacus (Rodale 81S-1024), and A. caudatus (CAC-20002), even though these values were of a higher range than what is usually reported.

\subsection{Crude Fiber}

Grain fiber consists of an edible plant cell wall, carbohydrates and polymers that occur naturally in the food as consumed. The best sources of fiber are whole grains and bran, especially the outer part of the grain called kernel layers, which consist of pericarp, testa and aleurone [72,73]. Crude fiber was increased remarkably by combined solution with a $60 \% \mathrm{Zn}+40 \%$ Fe ratio as well as other ratios. This could be possibly linked with a significant accumulation of $\mathrm{Zn}$ and Fe in aleurone, endosperm, and embryo [22,27] when these micronutrients are supplied to wheat, as discussed in different literature $[13,22,74]$. It can also be a result of assimilates remobilization in which process $\mathrm{Zn}$ and Fe have a greater role.

\subsection{Crude Protein}

The effect of the foliar application of combined $\mathrm{Zn}$ and Fe fertilizers on crude protein kept changing among treatments. A $100 \% \mathrm{Zn}$ solution did not differ significantly from the control, but a solution with $80 \% \mathrm{Zn}$ and $20 \%$ Fe ratio increased crude protein significantly. More precisely, as the fertilizer quantity increases, crude protein tends to decrease in this particular solution, which makes $80 \% \mathrm{Zn}+$ $20 \% \mathrm{Fe}_{5.5}$ the best performer for crude protein. This enhancement in grains quality may be due to the role of microelements in maintaining balanced plant physiological growth and activation of plant enzymes. There is a fluctuating effect in solutions made with $60 \% \mathrm{Zn}+40 \% \mathrm{Fe}, 40 \% \mathrm{Zn}+60 \% \mathrm{Fe}$, 
and $20 \% \mathrm{Zn}+80 \%$ Fe fertilizer ratios; some show a significant decrease, and others a non-significant effect, which makes these solutions unsuitable for protein increment in whole grain. Moreover, the $100 \%$ Fe solution is completely not ideal, because it significantly reduced crude protein. The lowest value was found with $100 \% \mathrm{Fe}_{5.5}$. These results differ from those reported by Melash et al. [75] in a study conducted in Ethiopia which revealed that $\mathrm{FeSO}_{4}$ tended to improve grain protein and gluten content as well as Zeleny index, compared to $\mathrm{ZnSO}_{4}$. Micronutrients and their interactions affect the physiological processes of plants, which has a significant impact on grain yield and quality [76]. These results partially reflect what was reported by Singh et al. [8] in a pot experiment conducted in Turkey. Furthermore, Zhang et al. [77] stated that foliar Zn application has a small effect on protein concentration and gluten characteristics. Average of two cropping seasons, $60 \% \mathrm{Zn}+40 \% \mathrm{Fe}, 40 \%$ $\mathrm{Zn}+60 \% \mathrm{Fe}$ and $20 \% \mathrm{Zn}+80 \% \mathrm{Fe}$ and $100 \%$ Fe ratios present lower protein content than control. However, literature shows evidence that the quantity of grain protein hugely affects the grain capacity in storing $\mathrm{Zn}$ and $\mathrm{Fe}$, which was confirmed by positive correlations between $\mathrm{Zn}$, Fe and protein in different wheat genotypes $[28,78,79]$. This was not confirmed in the present research, as high quantities did not correspond to high protein concentration.

\subsection{Zn Concentration}

Zinc applied alone enhanced the Zn concentration of whole grain. As the concentration of Zn decreases and Fe increases in the applied solution, there is a tendency of decreasing $\mathrm{Zn}$ concentration in grains. Studies reported that generally, the $\mathrm{Zn}$ concentrations in grain within wheat-cultivated regions range from $20-35 \mathrm{mg} \mathrm{kg}^{-1}$, with an average value around $28-30 \mathrm{mg} \mathrm{kg}^{-1}[4,18]$. Although the combination of $\mathrm{Zn}$ and $\mathrm{Fe}$ in different ratios and quantities relatively increased $\mathrm{Zn}$ concentration, treatments consisting of $\mathrm{Zn}$ alone registered high grain $\mathrm{Zn}$ concentration. The results are in agreement with Zhang et al. [77], who reported that foliar application of only $0.4 \% \mathrm{ZnSO}_{4} .7 \mathrm{H}_{2} \mathrm{O}$ increased $\mathrm{Zn}$ content in grain by $58 \%$, and Zou et al. [48], who reported an increase of up to $83 \%$ of $\mathrm{Zn}$ in grain. Moreover, studies have also mentioned an increase of $27 \% \mathrm{Zn}$ in rice and $9 \%$ in maize [18] when $\mathrm{Zn}$ is applied as foliar fertilization.

A possible reason for this increment is that foliar-applied $\mathrm{Zn}$ is phloem-mobile, and can be readily translocated into emerging grains in wheat $[33,80]$. The concentration of $\mathrm{Zn}$ decreased with high Fe quantities, and $100 \% \mathrm{Fe}_{13}$ showed the lowest $\mathrm{Zn}$ concentration, which could be explained by the antagonism of $\mathrm{Fe}$ and $\mathrm{Zn}$ when Fe is applied in high quantities as it was reported by Alam [81] and Alloway [64]. The same results were obtained by Ghamesi [82] in a study on Iron interaction with Copper, Zinc, and Manganese in wheat. Similarly, Verma and Tripathi [67] reported the same observations for a submerged paddy, as well as Brar and Sheklon [66], who reported that $\mathrm{Zn}$ translocation decreased as Fe increased. Aciksoz et al. [78] reported that in their study, Fe spray caused a not large decrease in grain $\mathrm{Zn}$ concentration, which was described as an undesirable effect of foliar Fe spray on grain $\mathrm{Zn}$. Moreover, it was reported that foliar application of Fe decreased the concentration of $\mathrm{Zn}$ in the leaves and roots of tomato [83]. In the present study, $100 \% \mathrm{Fe}_{13}$ and $100 \% \mathrm{Fe}_{9.5}$ registered lower $\mathrm{Zn}$ concentration than control, which highlights the negative effect of Fe foliar application on grain Zn.

\subsection{Fe Concentration}

Generally, the foliar application of combined $\mathrm{Zn}$ and Fe fertilizers improved grain Fe concentration in both years. However, only $100 \% \mathrm{Zn}_{5.5}, 80 \% \mathrm{Zn}+20 \% \mathrm{Fe}_{9.5}, 20 \% \mathrm{Zn}+80 \% \mathrm{Fe}_{5.5}$ and $100 \% \mathrm{Fe}_{13}$ improved Fe concentration in the first year, while almost all except treatments $100 \% \mathrm{Zn}_{13}$ enhanced grain Fe concentration in the second year. An increase of Fe by $\mathrm{Zn}$ application was also reported by Wang et al. [76], where the foliar application of $Z n$ resulted in a significant increase in Fe concentration. Despite a strong correlation between grain $\mathrm{Zn}$ and Fe, recently Cakmak et al. [22] reported that, in contrast to the positive effects of $\mathrm{Zn}$ fertilization on grain $\mathrm{Zn}$ concentrations, soil or foliar applications of various organic and inorganic forms of Fe fertilizers cannot influence grain Fe concentrations of durum wheat. Our results reflected partially the same observations in the first year, but the fact was 
not verified in the second year. The effect of Fe in increasing grains Fe concentration is still debatable. While in China [54] and Iran [84] foliar spray of $\mathrm{FeSO}_{4}$ increased grain Fe concentration by $21 \%$ and $14 \%$, respectively, it showed no effect on grain Fe concentration in Canada [85]. Moreover, Aciksoz et al. believe that, in their study, the increase in grain Fe concentration of $14 \%$ and $10 \%$ from FeEDTA and $\mathrm{FeSO}_{4}$ respectively, was due to the plant $\mathrm{N}$ status [78]. The high increase of grain Fe concentration was observed in a $100 \% \mathrm{Zn}$ ratio, but it was inversely proportional to its quantities; $100 \% \mathrm{Zn}_{5.5}>$ $100 \% \mathrm{Zn}_{9.5}>100 \% \mathrm{Zn}_{13}$. This gives an idea that high quantities of $\mathrm{Zn}$ spray fertilizers are not ideal in increasing the grain Fe. The increase with $100 \% \mathrm{Zn}$ treatments could be explained by the simultaneous increase of $\mathrm{Fe}$, due to a translocation of $\mathrm{Zn}$ from vegetative parts to grains, which is coordinated by same transporters, even though this Fe might not contribute a lot to flour Fe concentration, due to its peripheral location in grain $[54,86]$. Most of the times it is removed during the flour making process. Same observations were made by Li et al. [50] in the study conducted in China for assessing Zn and Fe concentrations in wheat flour affected by foliar applications of $\mathrm{Zn}$, and macronutrients and the same mechanism might have contributed to other ratio as well.

\section{Conclusions}

In the present study, 19 treatments were used including the control, Zn, Fe and combined $\mathrm{Zn}$ and Fe. Different combinations of fertilizer ratios and quantities were studied, and a possible increase was observed in these study variables. It was observed that $\mathrm{Zn}$, combined with small percentage of $\mathrm{Fe}$ in the solution, reduced the yield, while a higher percentage increased the yield. Zn applied alone was better in increasing $\mathrm{Zn}$ concentration in wheat grains, and higher quantities tended to highly increase its concentrations in grains. Fe applied alone has a good effect on its concentration in grains, but it did not differ much in the effects of treatments containing a low quantity of $\mathrm{Zn}$. Combined $\mathrm{Zn}$ and Fe treatments increased $\mathrm{Zn}$ and Fe content, but applying these micronutrients separately was still better than combining them to increase their concentration in wheat grain. The consistent positive impact was also seen in crude protein, and crude fiber, while crude fat was unaffected by any treatment.

However, there was a fluctuation among results with the same fertilizer ratio, and some observations do not reflect what was expected, such as a correlation between $\mathrm{Zn}$ and protein. Therefore, further studies are required to explore the genetic implications of this combination of fertilizers upon grain quality.

Supplementary Materials: The following are available online at http://www.mdpi.com/2073-4395/9/5/250/s1, Table S1: Analysis of covariance of the effects of experimental factors and their interactions on grain yield, Thousand Kernel Weight (TKW), spike length and kernels per spike, Table S2: Analysis of covariance of the effects of experimental factors and their interactions on crude fat, crude fiber, crude protein, Zinc content and iron content.

Author Contributions: Conceptualization, E.N. and J.B.H.; Formal analysis, E.N. and A.T.; Investigation, E.N., A.T., I.M., W.A.N., Y.P.Y. and B.M.W.; Methodology, E.N. and J.B.H.; Project administration, J.B.H.; Writing-original draft, E.N.; Writing—review \& editing, E.N.

Funding: This research was funded by the National high technology development plan (863) (2013AA102902).

Conflicts of Interest: The authors declare no conflict of interest.

\section{References}

1. FAO. FAO Statistical Pocket Book: World Food and Agriculture; FAO: Rome, Italy, 2015.

2. Tilman, D.; Cassman, K.G.; Matson, P.A.; Naylor, R.; Polasky, S. Agricultural sustainability and intensive production practices. Nature 2002, 418, 671. [CrossRef] [PubMed]

3. World Bank. World Bank Country and Lending Groups. Available online: https://datahelpdesk.worldbank. org/knowledgebase/articles/906519-world-bank-country-and-lending-groups (accessed on 17 April 2019).

4. Graham, R.D.; Welch, R.M.; Saunders, D.A.; Ortiz-Monasterio, I.; Bouis, H.E.; Bonierbale, M.; De Haan, S.; Burgos, G.; Thiele, G.; Liria, R. Nutritious subsistence food systems. Adv. Agron. 2007, 92, 1-74. 
5. Who, J.; Consultation, F.E. Diet, Nutrition and the Prevention of Chronic Diseases; WHO Technicl Report Series, No.916; WHO: Geneva, Switzerland, 2003.

6. Müller, O.; Krawinkel, M. Malnutrition and health in developing countries. CMAJ 2005, 173, $279-286$. [CrossRef] [PubMed]

7. Welch, R.M.; Graham, R.D. Breeding for micronutrients in staple food crops from a human nutrition perspective. J. Exp. Bot. 2004, 55, 353-364. [CrossRef]

8. Singh, B.R.; Timsina, Y.N.; Lind, O.C.; Cagno, S.; Janssens, K. Zinc and iron concentration as affected by nitrogen fertilization and their localization in wheat grain. Front. Plant Sci. 2018, 9, 307. [CrossRef]

9. Hotz, C.; Brown, K.H. Assessment of the Risk of Zinc Deficiency in Populations and Options for Its Control. Food Nutr. Bull. 2004, 25, S99-S203.

10. WHO. World Health Statistics; WHO: Geneva, Switzerland, 2012.

11. Murray, C.J.; Lopez, A.D. Measuring the global burden of disease. N. Engl. J. Med. 2013, 369, $448-457$. [CrossRef]

12. WHO. World Health Statistics; WHO: Geneva, Switzerland, 2009.

13. Balk, J.; Connorton, J.; Wan, Y.; Lovegrove, A.; Moore, K.; Uauy, C.; Sharp, P.; Shewry, P. Improving wheat as a source of iron and zinc for global nutrition. Nutr. Bull. 2019, 44, 53-59. [CrossRef] [PubMed]

14. Roberts, C.; Steer, T.; Maplethorpe, N.; Cox, L.; Meadows, S.; Nicholson, S.; Page, P.; Swan, G. National Diet and Nutrition Survey: Results from Years 7 and 8 (Combined) of the Rolling Programme (2014/2015-2015/2016); Food Standards Agency: London, UK, 2018.

15. Branca, F.; Ferrari, M. Impact of micronutrient deficiencies on growth: The stunting syndrome. Ann. Nutr. Metab. 2002, 46, 8-17. [CrossRef]

16. Golden, M.H. The nature of nutritional deficiency in relation to growth failure and poverty. Acta Paediatr. 1991, 80, 95-110. [CrossRef]

17. Welch, R.M. Micronutrients, Agriculture and Nutrition; Linkages for Improved Health and Well Being. In Perspectives on the Micronutrient Nutrition of Crops; Scientific Publishers: Jodhpur, India, 2001; pp. 247-289.

18. Cakmak, I.; Kutman, U.B. Agronomic biofortification of cereals with zinc: A review. Eur. J. Soil Sci. 2018, 69, 172-180. [CrossRef]

19. Garvin, D.F.; Welch, R.M.; Finley, J.W. Historical shifts in the seed mineral micronutrient concentration of US hard red winter wheat germplasm. J. Sci. Food Agric. 2006, 86, 2213-2220. [CrossRef]

20. Shewry, P.R.; Pellny, T.K.; Lovegrove, A. Is modern wheat bad for health. Nat. Plants 2016, 2, 16097. [CrossRef]

21. Cakmak, I.; Kalayc1, M.; Ekiz, H.; Braun, H.; Kılınç, Y.; Yılmaz, A. Zinc deficiency as a practical problem in plant and human nutrition in Turkey: A NATO-science for stability project. Field Crops Res. 1999, 60, 175-188. [CrossRef]

22. Cakmak, I.; Pfeiffer, W.; McClafferty, B. Review: Biofortification of Durum Wheat with Zinc and Iron. Cereal Chem. 2010, 87, 10-20. [CrossRef]

23. Cakmak, I. Enrichment of cereal grains with zinc: Agronomic or genetic biofortification? Plant Soil 2008, 302, 1-17. [CrossRef]

24. Nair, M.K.; Augustine, L.F.; Konapur, A. Food-Based Interventions to Modify Diet Quality and Diversity to Address Multiple Micronutrient Deficiency. Front. Public Health 2016, 3. [CrossRef]

25. Nestel, P.; Bouis, H.E.; Meenakshi, J.; Pfeiffer, W. Biofortification of staple food crops. J. Nutr. 2006, 136, 1064-1067. [CrossRef]

26. Rengel, Z.; Batten, G.; Crowley, D.D. Agronomic approaches for improving the micronutrient density in edible portions of field crops. Field Crops Res. 1999, 60, 27-40. [CrossRef]

27. Cakmak, I.; Kalayci, M.; Kaya, Y.; Torun, A.A.; Aydin, N.; Wang, Y.; Arisoy, Z.; Erdem, H.; Yazici, A.; Gokmen, O.; et al. Biofortification and localization of zinc in wheat grain. J. Agric. Food Chem. 2010, 58, 9092-9102. [CrossRef]

28. Zhao, F.; Su, Y.; Dunham, S.; Rakszegi, M.; Bedo, Z.; McGrath, S.; Shewry, P. Variation in mineral micronutrient concentrations in grain of wheat lines of diverse origin. J. Cereal Sci. 2009, 49, 290-295. [CrossRef]

29. White, P.J.; Broadley, M.R. Biofortifying crops with essential mineral elements. Trends Plant Sci. 2005, 10, 586-593. [CrossRef] [PubMed]

30. Kutman, U.B.; Yildiz, B.; Cakmak, I. Improved nitrogen status enhances zinc and iron concentrations both in the whole grain and the endosperm fraction of wheat. J. Cereal Sci. 2011, 53, 118-125. [CrossRef] 
31. Barunawati, N.; Hettwer Giehl, R.F.; Bauer, B.; Von Wirén, N. The influence of inorganic nitrogen fertilizer forms on micronutrient retranslocation and accumulation in grains of winter wheat. Front. Plant Sci. 2013, 4, 320. [CrossRef] [PubMed]

32. Kutman, U.B.; Yildiz, B.; Cakmak, I. Effect of nitrogen on uptake, remobilization and partitioning of zinc and iron throughout the development of durum wheat. Plant Soil 2011, 342, 149-164. [CrossRef]

33. Erenoglu, E.B.; Kutman, U.B.; Ceylan, Y.; Yildiz, B.; Cakmak, I. Improved nitrogen nutrition enhances root uptake, root-to-shoot translocation and remobilization of zinc (65Zn) in wheat. New Phytol. 2011, 189, 438-448. [CrossRef]

34. Kutman, U.B.; Kutman, B.Y.; Ceylan, Y.; Ova, E.A.; Cakmak, I. Contributions of root uptake and remobilization to grain zinc accumulation in wheat depending on post-anthesis zinc availability and nitrogen nutrition. Plant Soil 2012, 361, 177-187. [CrossRef]

35. Persson, D.; de Bang, T.; Pedas, P.; Kutman, U.; Cakmak, I.; Andersen, B.; Finnie, C.; K Schjoerring, J.; Husted, S. Molecular speciation and tissue compartmentation of zinc in durum wheat grains with contrasting nutritional status. New Phytol. 2016, 211, 1255-1265. [CrossRef]

36. Shi, R.; Zhang, Y.; Chen, X.; Sun, Q.; Zhang, F.; Römheld, V.; Zou, C. Influence of long-term nitrogen fertilization on micronutrient density in grain of winter wheat (Triticum aestivum L.). J. Cereal Sci. 2010, 51, 165-170. [CrossRef]

37. Astolfi, S.; Cesco, S.; Zuchi, S.; Neumann, G.; Roemheld, V. Sulphur starvation reduces phytosiderophores release by Fe-deficient barley plants. Soil Sci. Plant Nutr. 2006, 52, 43-48. [CrossRef]

38. Zuchi, S.; Cesco, S.; Astolfi, S. High S supply improves Fe accumulation in durum wheat plants grown under Fe limitation. Environ. Exp. Botany 2012, 77, 25-32. [CrossRef]

39. Celletti, S.; Paolacci, A.R.; Mimmo, T.; Pii, Y.; Cesco, S.; Ciaffi, M.; Astolfi, S. The effect of excess sulfate supply on iron accumulation in three graminaceous plants at the early vegetative phase. Environ. Exp. Bot. 2016, 128, 31-38. [CrossRef]

40. Astolfi, S.; Pii, Y.; Terzano, R.; Mimmo, T.; Celletti, S.; Allegretta, I.; Lafiandra, D.; Cesco, S. Does Fe accumulation in durum wheat seeds benefit from improved whole-plant sulfur nutrition? J. Cereal Sci. 2018, 83, 74-82. [CrossRef]

41. Celletti, S.; Pii, Y.; Mimmo, T.; Cesco, S.; Astolfi, S. The characterization of the adaptive responses of durum wheat to different Fe availability highlights an optimum Fe requirement threshold. Plant Physiol. Biochem. 2016, 109, 300-307. [CrossRef]

42. Ciaffi, M.; Paolacci, A.R.; Celletti, S.; Catarcione, G.; Kopriva, S.; Astolfi, S. Transcriptional and physiological changes in the $\mathrm{S}$ assimilation pathway due to single or combined $\mathrm{S}$ and Fe deprivation in durum wheat (Triticum durum L.) seedlings. J. Exp. Bot. 2013, 64, 1663-1675. [CrossRef]

43. Zuchi, S.; Watanabe, M.; Hubberten, H.-M.; Bromke, M.; Osorio, S.; Fernie, A.R.; Celletti, S.; Paolacci, A.R.; Catarcione, G.; Ciaffi, M. The interplay between sulfur and iron nutrition in tomato. Plant Physiol. 2015, 169, 2624-2639. [CrossRef]

44. Borrill, P.; Connorton, J.M.; Balk, J.; Miller, A.J.; Sanders, D.; Uauy, C. Biofortification of wheat grain with iron and zinc: Integrating novel genomic resources and knowledge from model crops. Front. Plant Sci. 2014, 5, 53. [CrossRef]

45. de Valença, A.W.; Bake, A.; Brouwer, I.D.; Giller, K.E. Agronomic biofortification of crops to fight hidden hunger in sub-Saharan Africa. Glob. Food Secur. 2017, 12, 8-14. [CrossRef]

46. Frossard, E.; Bucher, M.; Mächler, F.; Mozafar, A.; Hurrell, R. Potential for increasing the content and bioavailability of Fe, Zn and Ca in plants for human nutrition. J. Sci. Food Agric. 2000, 80, 861-879. [CrossRef]

47. Welch, R.M.; Graham, R.D. A new paradigm for world agriculture: Meeting human needs: Productive, sustainable, nutritious. Field Crops Res. 1999, 60, 1-10. [CrossRef]

48. Zou, C.Q.; Zhang, Y.Q.; Rashid, A.; Ram, H.; Savasli, E.; Arisoy, R.Z.; Ortiz-Monasterio, I.; Simunji, S.; Wang, Z.H.; Sohu, V.; et al. Biofortification of wheat with zinc through zinc fertilization in seven countries. Plant Soil 2012, 361, 119-130. [CrossRef]

49. Peleg, Z.; Saranga, Y.; Yazici, A.; Fahima, T.; Ozturk, L.; Cakmak, I. Grain zinc, iron and protein concentrations and zinc-efficiency in wild emmer wheat under contrasting irrigation regimes. Plant Soil 2007, 306, 57-67. [CrossRef] 
50. Li, M.; Wang, S.; Tian, X.; Li, S.; Chen, Y.; Jia, Z.; Liu, K.; Zhao, A. Zinc and iron concentrations in grain milling fractions through combined foliar applications of $\mathrm{Zn}$ and macronutrients. Field Crops Res. 2016, 187, 135-141. [CrossRef]

51. Pataco, I.M.; Lidon, F.C.; Ramos, I.; Oliveira, K.; Guerra, M.; Pessoa, M.F.; Carvalho, M.L.; Ramalho, J.C.; Leitão, A.E.; Santos, J.P.; et al. Biofortification of durum wheat (Triticum turgidum L. ssp. durum (Desf.) Husnot) grains with nutrients. J. Plant Int. 2017, 12, 39-50. [CrossRef]

52. Chattha, M.U.; Hassan, M.U.; Khan, I.; Chattha, M.B.; Mahmood, A.; Chattha, M.U.; Nawaz, M.; Subhani, M.N.; Kharal, M.; Khan, S. Biofortification of Wheat Cultivars to Combat Zinc Deficiency. Front. Plant Sci. 2017, 8, 281. [CrossRef]

53. Buchholz, D.D.; Brown, J.R.; Garret, J.; Hanson, R.; Wheaton, H. Soil Test Interpretations and Recommendations Handbook; Division of Plant Sciences, University of Missouri-College of Agriculture: Columbia, MO, USA, 2004.

54. Zhang, Y.; Shi, R.; Rezaul, K.M.; Zhang, F.; Zou, C. Iron and Zinc Concentrations in Grain and Flour of Winter Wheat As Affected by Foliar Application. J. Agric. Food Chem. 2010, 58, 12268-12274. [CrossRef]

55. Arlington, V. Official Methods of Analysis of the Association of Official Analytical Chemists; Association of Official Analytical Chemists: Washington, DC, USA, 1921; Volume 2.

56. ISO 16634-1. Food Products-Determination of the Total Nitrogen Content by Combustion According to the Dumas Principle and Calculation of the Crude Protein Content: Oilseeds Animal Feeding Stuffs; ISO: Geneva, Switzerland, 2008.

57. Komarek, A.; Manson, H.; Thiex, N. Crude Fiber Determinations Using the ANKOM System; ANKOM Technology Corporation Publication: Macedon, NY, USA, 1996.

58. Thiex, N.J.; Anderson, S.; Gildemeister, B. Crude fat, diethyl ether extraction, in feed, cereal grain, and forage (Randall/Soxtec/submersion method): Collaborative study. J. AOAC Int. 2003, 86, 888-898.

59. Isaac, R.A.; Kerber, J.D. Atomic Absorption and Flame Photometry: Techniques and Uses in Soil, Plant, and Water Analysis. In Instrumental Methods for Analysis of Soils and Plant Tissue; Instrumentalmet; Soil Science Society of America: Madison, WI, USA, 1971; pp. 17-37.

60. Cakmak, I. Possible roles of zinc in protecting plant cells from damage by reactive oxygen species. New Phytol. 2000, 146, 185-205. [CrossRef]

61. Welch, R.M.; Allaway, W.H.; House, W.A.; Kubota, J. Geographic Distribution of Trace Element Problems. In Micronutrients in Agriculture; Micronutrientsi2; Soil Science Society of America, Inc.: Madison, WI, USA, 1991; pp. 31-57.

62. Zhang, Y.-Q.; Sun, Y.-X.; Ye, Y.-L.; Karim, M.R.; Xue, Y.-F.; Yan, P.; Meng, Q.-F.; Cui, Z.-L.; Cakmak, I.; Zhang, F.-S. Zinc biofortification of wheat through fertilizer applications in different locations of China. Field Crops Res. 2012, 125, 1-7. [CrossRef]

63. Gebbing, T.; Schnyder, H. Pre-anthesis reserve utilization for protein and carbohydrate synthesis in grains of wheat. Plant Physiol. 1999, 121, 871-878. [CrossRef]

64. Alloway, B.J. Zinc in Soils and Crop Nutrition; International Zinc Association: Brussels, Belgium, 2004.

65. Barak, P.; Helmke, P.A. The Chemistry of Zinc. In Zinc in Soils and Plants; Springer: Berlin, Germany, 1993; pp. 1-13.

66. Brar, M.S.; Sekhon, G.S. Interaction of Zinc with Other Micronutrient Cations, II. In Effect of Iron on Zinc 65 Absorption by Rice Seedlings and its Translocation within the Plants; Springer: Berlin, Germany, 1976; Volume 45, pp. 145-150.

67. Verma, T.S.; Tripathi, B.R. Zinc and Iron Interaction in Submerged Paddy; Springer: Berlin, Germany, 1983; Volume 72, pp. 107-116.

68. Rietra, R.P.; Heinen, M.; Dimkpa, C.O.; Bindraban, P.S. Effects of nutrient antagonism and synergism on yield and fertilizer use efficiency. Commun. Soil Sci. Plant Anal. 2017, 48, 1895-1920. [CrossRef]

69. Sumner, M.E.; Farina, M.P. Phosphorus Interactions with other Nutrients and Lime in Field Cropping Systems. In Advances in Soil Science; Springer: Berlin, Germany, 1986; pp. 201-236.

70. Fageria, V. Nutrient interactions in crop plants. J. Plant Nutr. 2001, 24, 1269-1290. [CrossRef]

71. Bressani, R.; Gonzalez, J.M.; Elias, L.G.; Melgar, M. Effect of fertilizer application on the yield, protein and fat content, and protein quality of raw and cooked grain of three amaranth species. Plant. Foods Hum. Nutr. 1987, 37, 59-67. [CrossRef] 
72. Raninen, K.; Lappi, J.; Mykkänen, H.; Poutanen, K. Dietary fiber type reflects physiological functionality: Comparison of grain fiber, inulin, and polydextrose. Nutr. Rev. 2011, 69, 9-21. [CrossRef] [PubMed]

73. Nagengast, F.; Hectors, M.; Buys, W.; Tongeren, J.V. Inhibition of secondary bile acid formation in the large intestine by lactulose in healthy subjects of two different age groups. Eur. J. Clin. Investig. 1988, 18, 56-61. [CrossRef]

74. Moore, K.L.; Zhao, F.-J.; Gritsch, C.S.; Tosi, P.; Hawkesford, M.J.; McGrath, S.P.; Shewry, P.R.; Grovenor, C.R. Localisation of iron in wheat grain using high resolution secondary ion mass spectrometry. J. Cereal Sci. 2012, 55, 183-187. [CrossRef]

75. Melash, A.A.; Mengistu, D.K.; Aberra, D.A.; Tsegay, A. The influence of seeding rate and micronutrients foliar application on grain yield and quality traits and micronutrients of durum wheat. J. Cereal Sci. 2018, 85, 221-227. [CrossRef]

76. Wang, S.; Li, M.; Tian, X.; Li, J.; Li, H.; Ni, Y.; Zhao, J.; Chen, Y.; Guo, C.; Zhao, A. Foliar zinc, nitrogen, and phosphorus application effects on micronutrient concentrations in winter wheat. Agron. J. 2015, 107, 61-70. [CrossRef]

77. Zhang, Y.-Q.; Deng, Y.; Chen, R.-Y.; Cui, Z.-L.; Chen, X.-P.; Yost, R.; Zhang, F.-S.; Zou, C.-Q. The reduction in zinc concentration of wheat grain upon increased phosphorus-fertilization and its mitigation by foliar zinc application. Plant Soil 2012, 361, 143-152. [CrossRef]

78. Aciksoz, S.; Yazici, A.; Ozturk, L.; Cakmak, I. Biofortification of wheat with iron through soil and foliar application of nitrogen and iron fertilizers. Plant Soil 2011, 349, 215-225. [CrossRef]

79. Gomez-Becerra, H.F.; Erdem, H.; Yazici, A.; Tutus, Y.; Torun, B.; Ozturk, L.; Cakmak, I. Grain concentrations of protein and mineral nutrients in a large collection of spelt wheat grown under different environments. J. Cereal Sci. 2010, 52, 342-349. [CrossRef]

80. Haslett, B.; Reid, R.; Rengel, Z. Zinc mobility in wheat: Uptake and distribution of zinc applied to leaves or roots. Ann. Bot. 2001, 87, 379-386. [CrossRef]

81. Alam, S.; Kamei, S.; Kawai, S. Effect of iron deficiency on the chemical composition of the xylem sap of barley. Soil Sci. Plant Nutr. 2001, 47, 643-649. [CrossRef]

82. Ghasemi-Fasaei, R.; Ronaghi, A. Interaction of iron with copper, zinc, and manganese in wheat as affected by iron and manganese in a calcareous soil. J. Plant Nutr. 2008, 31, 839-848. [CrossRef]

83. Kaya, C.; Higgs, D.; Burton, A. Foliar application of iron as a remedy for zinc toxic tomato plants. J. Plant Nutr. 1999, 22, 1829-1837. [CrossRef]

84. Pahlavan Rad, M.; Pessarakli, M. Response of Wheat Plants to Zinc, Iron, and Manganese Applications and Uptake and Concentration of Zinc, Iron, and Manganese in Wheat Grains. Commun. Soil Sci. Plant Anal. 2009, 40, 1322-1332. [CrossRef]

85. Gupta, U.C. Iron status of crops in Prince Edward Island and effect of soil pH on plant iron concentration. Can. J. Soil Sci. 1991, 71, 197-202. [CrossRef]

86. Curie, C.; Cassin, G.; Couch, D.; Divol, F.; Higuchi, K.; Le Jean, M.; Misson, J.; Schikora, A.; Czernic, P.; Mari, S. Metal movement within the plant: Contribution of nicotianamine and yellow stripe 1-like transporters. Ann. Bot. 2008, 103, 1-11. [CrossRef]

(C) 2019 by the authors. Licensee MDPI, Basel, Switzerland. This article is an open access article distributed under the terms and conditions of the Creative Commons Attribution (CC BY) license (http://creativecommons.org/licenses/by/4.0/). 